\title{
Celebrating Peter Redpath and His Library
}

\section{by the Editors}

This celebratory amthology brings together a number of previously published texts, now long out of print, about Peter Redpath and the Redpath Library. Mc Gill Principal (1855-1893) Sir William Dawson's In Memoriam is taken from a pamphlet publihsed in 1894 by the University to commemorate one of its greatest benefactors. The extract from Sydney B. Mitchell's autobiography Mitchell of California describes the early years of the Redpath Library through the eyes of a student and librarian. The section reprinted here from the Report of the City of Manchester Libraries Committee provides an interesting comment on the state of libraries in Canada in 1908. Finally, the article by the University Librarian (1920-1947), Dr. Gerhard R. Lomer, on the first half-century of the Redpath Library is a survey of what the University Iibrary has accomplished since its founding and the challenges that it faces. These rexts are complemented by photographs of the Redpath Library from various periods of its history

Cette anthologie commémorative réunit un certain nombre de textes déjà publiés, mais depuis longtemps épuisés, écrits à propos de Peter Redpath et de la bibliothèque Redpath. L'article In Memoriam du principal de Mc Gill. (1855-1893), Sir William Dawson, est tiré d'un opuscule publié en 1894 par l'Université pour rendre hommage à l'un de ses grands bienfaiteurs. L'extrait de l'autobiographie, intitulée Mitchell of California, par Sydney $B$. Mitchell relate les premières années de l'existence de la bibliothèque Redpath vues à travers les yeux d'un étudiant et d'un bibliothécaire. La partie réimprimée ici, qui provient du Report of the City of Manchester Libraries Committee (Rapport du Comité des bibliothèques de la ville de Manchester) donne un aperçu intéressant de la situation des hibliothèques au Canada en 1908. Enfin, l'article du D' Gerhard R. Lomer (1920-1947), bibliothécaire de l'Université, qui parle du premier demi-siècle d'histoire de la bibliothèque Redpath, rend compte des réalisations de cette bibliothèque universitaire intervenues depuis sa fondation et des enjeux auxquels elle fait face. Ces textes sont assortis de photographies représentant la bibliothèque Redpath à différentes périodes de son histoire.

\section{In Memoriam: Peter Redpath}

by Sir William Dawson

$\mathrm{I}$ a biographical sketch of the founder of McGill University, prepared by the writer many years ago, the remark was made that men of the stamp of James McGill are of rare occurrence in the British colonies. At that time it could not have been anticipated that other benefactors of McGill University, animated by a similar spirit, were so soon to arise, and some of them giving still larger sums in aid of education. We may now reckon among such men the late Mr. William Molson, the late Sir W. E. Logan, the late Major Hiram Mills, the late Mr. David J. Greenshields, the late Mr. Thomas Workman, the Hon. Sir D. A. Smith, Mr. W. C. McDonald, Mr. and Mrs. J. H. R. Molson and many others, as well as the honoured subject of the present memorial, which is to be regarded not as a mere official record, but as a tribute of affectionate esteem and gratitude on the part of all connected with the University, and more especially of the Committee charged with the care of the Peter Redpath Museum.

Mr. Peter Redpath was born in Montreal, on August 1st, 1821. He was educated in St. Paul's School, Montreal, then one of the best institutions of higher education in his native Province, under the Rev. Dr. Black. He was one of the best pupils of a large class, and, as I am informed by one of his fellow-students, earned the respect and love of his class-mates by his equable and amiable temper and his kindness to the junior boys. After completing his course in St. Paul's School, he spent some time in England in further study and in acquiring business training. On his return to Montreal, and from the time when he first entered on business and public life, he took a leading position as one of the most prominent and honoured citizens of his native place. He was recognized as a man equally remarkable for sterling integrity, sound judgment, refined tastes and a benevolent and kindly disposition; while the possession of wealth enabled him at once to gratify his own higher tastes and to carry out his wise 
and benevolent plans for the welfare of his fellow-men.

His father, Mr. John Redpath, was one of those strong, earnest, pious and clear-headed men of whom Scotland has supplied so many to build up the colonies of the empire. A leader in the Church to which he belonged, and one of its office-bearers, he was a diligent and sagacious man of business, and displayed his ability in this way by founding the first sugar refinery in Canada, and one of the largest on the American continent. He was a valued director of the Bank of Montreal and other business-enterprises, a member of the City Council at a time when it was justly held to be composed of the élite of the citizens, and would have been Mayor but for his generous preference of a friend. He was an earnest promoter of the improvement of the city, and set an example by the widening of streets and planting of trees on his own property. While amassing for himself a considerable fortune, and laying out with taste his beautiful property of Terrace Bank, he was ever ready to contribute freely of his means and to give his time and thought to every deserving public object. He was one of the founders of the Educational Institute at Point aux Trembles, and of the Presbyterian College of Montreal, a subscriber to the first endowment-fund of McGill University, and a governor of and liberal contributor to the Montreal General Hosptial. In all this his son was a worthy successor, continuing and enlarging the public services and benefactions of his father, and bringing them into relation with the advancing needs and opportunities of a new generation. As an educational benefactor, the name of Mr. Peter Redpath will ever be remembered in connection with the Museum, the Library and the University-chair which bear his name; but he also took part in nearly all the Subscriptions for general and special purposes in the University from 1856 downwards.

Mr. Redpath was married on October 16th, 1847, to Miss Grace Wood, the daughter of a gentleman of Manchester, England, noted among his fellow-citizens as an eminent promoter of philanthropic objects. Mrs. Redpath survives her husband, and is his executrix, not merely in the legal sense, but as one wisely and loyally desirous to carry out his wishes, and herself deeply interested in the educational and benevolent enterprises of her deceased husband. In evidence of this, she contributed to his last great gift of the new Library- building the two large and elaborate stained glass windows containing portraits of illustrious men in literature, science and art, which adorn the public reading room.

In his connection with the University, as a member of its Governing Board, to which he was appointed in 1864 , and of which at the time of his death he was the senior member, Mr. Redpath was invaluable. $\mathrm{He}$ regularly attended the meetings, was always interested in the questions under discussion, and ready to give aid, advice and influence in favour of every measure of improvement. In the midst of many other avocations, he was always alive to its interests, and was constantly contributing to its advancement in many quiet and thoughtful ways. He was also a friend on whom every officer of the University could reckon, as kind and helpful in any difficulty or emergency; and he possessed that breadth of view which enabled him to make allowance for the failings of weaker men. One instance of his continued and painstaking liberality was the contribution from year to year of rare and valuable books on English history, selected for him by competent experts, until that Department of the University Library has become noted for its completeness and the treasures which it contains. After his removal to England, in 1880, he continued to take the same lively interest in the University, as was evidenced by his great benefactions after that date. $\mathrm{He}$ also kept up a regular correspondence with the Principal and others respecting its affairs, and acted in its behalf whenever necessary. In this respect his presence in England was often of the greatest service, and many members of the University cherish a grateful remembrance of the kindness and hospitality with which he received them in the old Manor House of Chiselhurst, which was his English home.

He acquired this property in 1880 as a permanent English residence, and took great pleasure in restoring and improving the house and grounds, till it became an ideal English country house of the olden type. The place was not only quaint and beautiful in itself, but was full of historic associations. It had been the home of Joan, the "Fair Maid of Kent, " the wife of the Black Prince, and was successively in the possession of the Duke of Somerset, of Warwick the "King-maker," and of the Duke of Clarence; and, reverting to the crown in the reign of Henry VIII, was granted by Queen 


\section{Celebrating Peter Redpath and His Library}

Elizabeth as a suburban residence to her great statesman, Sir Francis Walsingham, where she is said to have sometimes visited him. In Mr. Redpath's possession it has opened its hospitable doors to many noted men of our own time. To a man of his tastes it afforded the pleasures of country life and of literary leisure, with ready access to London and all its advantages as well as facilities for extending hospitality to old Canadian friends whom business or pleasure brought to the Metropolis.

Mr. Redpath's life in England was not altogether one of repose. He engaged in serious legal studies, and became a member of the Middle Temple. He was on the London Board of the Bank of Montreal. He was a member of the Council of the Canadian Institute, took much interest in the question of Imperial Federation, and represented the North-West Territories on the Board of the Royal Imperial Institute.

Mr. Redpath visited Canada frequently after his removal to England, the last time being in the autumn of 1893, when he was accompanied by Mrs. Redpath. After a tour in the North-West, they returned to Montreal to be present at the opening of the New Library in October. He was at that time apparently in good health and spirits, appeared to enjoy the society of his old friends, and superintended with the greatest interest the completion of the beautiful new building which he had presented to the University, and the planning of which had occupied much of his thought in the two previous years.

After his retum to England, no intimation of any serious illness had reached Montreal, when, on the Ist of February, the news of his sudden and unexpected death, received by cable, fell like a thunder-clap on his many friends. No event, it may be truly said, ever cast a deeper gloom on all connected with the McGill University and the institutions associated with it. For the moment everyone seemed paralyzed, and the only thought seemed to be how it would be possible to express sympathy with the bereaved widow, to take part, by representatives in England, in the obsequies at Chiselhurst, and to engage in a memorial service in Montreal on the 6th of February, the day of the funeral in England. This last tribute, though hastily arranged, was most sincere and impressive. It was held in the reading-room of the New Library, so recently opened in the presence of its now deceased founder. The service was attended by all connected with the University and by many of the leading citizens of Montreal, and, as it proceeded, many moistened eyes testified to the esteem and affection with which $\mathrm{Mr}$. Redpath was regarded. The following are extracts from the address delivered on the occasion by his friend and former Pastor, Rev. Dr. MacVicar, Principal of the Presbyterian Theological College:-

We unite this morning at the same hour in which his funeral service is being conducted at Chiselhurst, England, in a public tribute of respect and honour to the memory of Mr. Peter Redpath. He was a man of good ability, sound judgment, refined and elevated taste, and excellent culture--a lover of literature and art; and, what is infinitely better, a lover of truth and of the God of Truth. After a long and successful career, having retired from business, he removed to England, and both in this city and the old land was deservedly called to occupy many positions of trust and responsibility. In business he was uniformly characterized by indefatigable diligence and unswerving integrity. His yea was yea, and his nay, nay. Gentle, amiable and considerate of the opinions and feelings of others, ever ready to take a broad and generous view of their actions, and yet, when purity and principle were concerned, he was as firm as a rock. It was vain for those who had sinister ends to serve to attempt to turn him aside from truth and righteousness. In these respects he fumished a notable pattern, which young men and all others may do well to imitate. As a philanthropist he took rank with the foremost in our land. His benefactions in various forms to McGill University and other public institutions bear witness to his unstinted liberality. $\mathrm{He}$ had grace and wisdom given him to administer his large resources in his life-time for the good of his fellow men; and this fact deserves to be emphasized. His last public appearance amongst us was in this very 
hall, three months ago, in the performance of a crowning act of educational usefulness. But let it not be supposed that all his benevolence took visible forms like those just mentioned. He was naturally unobtrusive, strongly averse to all ostentatious display and vulgar advertising of the good he purposed or accomplished. His unreported charities were numerous and wisely distributed. He sought to do his alms before God, and not before men to be seen of them. The Father who seeth in secret alone knoweth in what abundant measure he gave help and comfort to others. As a Christian he was devout, conscientious, and consistent. His Christianity was a life and character rather than a demonstrative profession. I had opportunities of knowing his views on these matter intimately. For many years he was an exemplary member and officebearer of the Free Church, Côte Street, now Crescent Street Church. He served with me there most faithfully as a deacon during my entire pastorate, and was twice elected as an elder, the duties of which office, through the modest estimate of his own ability, he judged himself unable to undertake. His simple trust in the word and in the Christ of God was the secret of his meek and quiet spirit, unfailing generosity and sterling worth. And I must add that in all his Christian service and public munificence he was lovingly aided by his partner in life, with whom, in her great bereavement, we to-day deeply sympathize. Finally, in this hour of sorrow over the removal of one of Montreal's noble benefactors, let us seek, through the mediation of Jesus Christ, the help of His Holy Spirit, that we may emulate the example of him whose memory we honour.

Resolutions of condolence were passed by many public bodies with which $\mathrm{Mr}$. Redpath had been connected or to which he had given assistance. The following resolutions of the Corporation of the University and of the Faculty of Arts may be given as examples:--

The Corporation of McGill University, on occasion of its first meeting after the lamented decease of Mr. Peter Redpath, one of the Governors of this University and one of its leading benefactors, desires to place on record its deep and grateful sense of the benefits conferred by $\mathrm{Mr}$. Redpath on the cause of higher education in Canada, not only by his liberal benefactions, but by his earnest, wise and practical interest in all that concerned the welfare of this University.

In addition to many other acts of liberality, the Corporation recalls his large contributions, extended throughout many years, towards the formation in the University Library of a complete collection of Standard Works and original Records on the subject of English History, and his crowning gifts in the endowment of the Chair of Mathematics, and the erection and equipment of the Museum and Library Buildings which bear his name, together with the contribution of funds for their maintenance.

In connection with these benefactions, the Corporation hails with satisfaction the effort now being made by friends and admirers of Mr. Redpath in England and Canada to provide a suitable monument to be placed in the Library, and desires to commend to the favourable consideration of the Board of Governors the proposal of the Museum Committee that a memorial tablet be placed in the Museum, and that a special number of the Museum Memoirs be prepared, giving the history of this department since the announcement of the benefaction in 1880 , with a biographical sketch of Mr. Redpath.

That the expression of the sincere sympathy of the University be conveyed to Mrs. Redpath and to the other relatives of the deceased in this country and in England. 
The members of the Faculty of Arts of McGill College, meeting on the day when the mournful intelligence has arrived of the death of their common friend and benefactor, Mr. Peter Redpath, and remembering his many munificent, wise and thought ful gifts to this University, and especially to this Faculty, more particularly the Chair of Mathenatics, with the costly Museum and the Library which bear his name, desire to express their high appreciation of the qualities of intellect and of heart which led him to set so high a value on sound leaming, both in literature and in science, and by which he was prompted, in so many conspicuous ways and with such princely liberality and untiring zeal, to promote the full equipment and efticiency of this Faculty. His efforts in the cause of Higher Education have won a name and place for him among the benefactors, not of this University only, but of his country at large, and have brought him lasting and well-deserved renown. The members of the Faculty further desire to give expression to their heartfelt sorrow and sympathy with her who has for so many years been his partner in life and the true helpmate and sympathizer with him in his many and varied acts of beneficence for the good of his fellow citizens and of mankind. To the members of the family of the deceased residing in Canada the Faculty respectfully desire to tender their condolence in the loss they have sustained.

Many literary and scientific periodicals and leading organs of public opinion in Great Britain and the Colonies noticed his large scientific and educational benefactions and endowments, and paid deserved tribute to his memory. The following from the London Times may be quoted in illustration:-

Besides great business aptitude, Mr. Redpath was a man of high culture and wide sympathies. Thus he was President of the General Hospital of Montreal, and took and active interest in the McGill
College and University there, which owes so much to the munificence of individual Canadians. In $1880 \mathrm{Mr}$. Redpath built, at his sole expense, a museum in connection with the University, intended as a place of deposit and study of specimens in geology, mineralogy, palæontology, zoology, botany and archæology. The foundation stone of this building, a striking architectural ornament to the University, was laid by the Marquis of Lome, when Governor-General, and was then described by the Principal, Sir William Dawson, as one of the largest and most generous gifts ever made to the University or to the cause of education in Canada. More recently Mr. Redpath made a still more considerable addition to the University buildings in a spacious and handsome Library, for the use of undergraduates in the Faculties of Arts, Applied Science, Medicine and Law, which was opened at Montreal on October 31 st, 1893, amid great rejoicings, in the presence of the Governor-General, the Earl of Aberdeen, Lady Aberdeen, and a large gathering of representative Canadians. Mr. and Mrs. Redpath were present on this occasion, and Lord Aberdeen made graceful allusion to the chief gift, as well as to that of some fine stained windows, part of the decorations of the hall, by Mrs. Redpath. Not contented with providing the funds (which did not fall far short of $£ 75,000$ ) for the erection of the Museum and Library, Mr. Redpath devoted much time and study in examining similar structures in England and abroad, with a view to secure the best clesigns and most convenvient equipment for the latter. As a result of his carefullythought-out plans, the library, for its size (it will hold some 130,000 volumes), affords by its arrangements for readers and the housing of books an accommodation hardly equalled in any other such institution. For some years past Mr. Redpath, though a frequent visitor to Canada, has settled in England, 
where he became a member of the Middle Temple, was elected on the London Board of the Bank of Montreal (of which his father had been a director), and busied himself in helping to furnish the new museum and library in Montreal by frequent contributions of specimens and books purchased in Europe. He also took much interest in the Royal Colonial Institute, serving on the council of that body, and was member of the governing body of the Royal Imperial Institute, being specially appointed to represent the NorthWest Territories of the Dominion. His death, which took place at his residence, the Manor House, Chiselhurst, in his 73rd year, will be deplored on both sides of the Atlantic by a wide circle of friends, to whom his genial manners, high sense of honour, and active, unobtrusive benevolence had greatly endeared him.

The Canadian Gazette of London gives the following testimony to his career and to the estimation in which he was held by his countrymen:-

His memory will be chiefly cherished by reason of his broad and liberal sympathy with the cause of higher education. Though not a resident of Canada for many years past, he never forgot that it was in Canada that his wealth had been acquired, and so long as the name of McGill University survives, Canadians will need no other monument to the wisely-planned munificence of Peter Redpath. As far back as 1871 he devoted $\$ 20,000$ to the foundation of a chair of Natural Philosophy, and promisd an annual subscription of $\$ 400$ for ten years in aid of the Faculty of Applied Science. Nine years later, following in the footsteps of his friend Sir Donald Smith, he marked the semi-jubilee of Sir Wiliam Dawson's principalship by announcing his intention to erect a costly and capacious museum building on the college grounds, wherein the large geological collections of the Principal, and the collections of Dr. P. P.
Carpenter, Dr. Holmes, and others, might be fittingly housed. In September of that year the foundation stone was laid by the Governor-General, Lord Lorne, and at the close of 1881 the handsome dressed limestone building, which still remains the finest of its kind in Canada, was completed, at a cost of about $\$ 140,000$, besides a large annual sum for the cost of maintenance for ten years.

Subsequently, however, Mr. Redpath made an even more substantial gift to Canada's foremost University, in the form of a new university library. The proceedings at the opening of this library on the last day of October will be fresh in the memory of our readers. The Governor-General was present in his capacity as official Visitor of the College, accompanied by Lady Aberdeen; and the large gathering, representative of all classes of the community, which then assembled, little thought that they were taking part in the last public act of one of the most faithful of McGill's benefactors. Both Mr. and Mrs. Redpath were present, and the Governor-General, when receiving a beautifully-wrought gold key, the presentation of which symbolized the transfer of the building to the University, made graceful reference to the enlightened and generous public spirit which had ever signalized the attitude of the leaders of Montreal commerce, and Mr. Redpath chief among them, towards the cause of higher education. "Many years of a successful and upright career, and of much public usefulness, have," said Lord Aberdeen, "rendered the worth and name of $\mathrm{Mr}$. Peter Redpath so familiar that it is unnecessary, nor would it in his presence be acceptable to himself, to dilate upon his claims to public esteem and good-will." These remarks fittingly describe the appreciation in which $\mathrm{Mr}$. Redpath was held in all parts of Canada. His Excellency also spoke of the share Mrs. Redpath had in the presentation of that day, for the beautiful stained glass 
windows at each end of the library were her gift. This was the last public appearance of Mr. Redpath, and he had thus the satisfaction of witnessing the completion of this his final act of educational beneficence.

In England Mr. Redpath was one of the best-known friends of Canada. No Dominion day dinner or Canadian festival was deemed complete without his genial presence, and though his name seldom figured upon toast lists and the like, he was always one of the foremost to advance any worthy Imperial or AngloCanadian movement. From its commencement he, together with the late Sir Alex. Galt and Mr. R. R. Dobell, represented Canada upon the general committee of the Imperial Federation League. He took much interest in the Royal Colonial Institute, serving on the council of that body, and he was appointed to represent the North-West Territories upon the governing body of the Imperial Institute. He was, moreover, a member of the London Board of the Bank of Montreal, of which his father had been President, and was upon the directorate of that other well-known Canadian institution, the Canada Company. Thus his thoughts and activities were ever directed to the advancement of the best interests of the country which had given him birth and prosperity, and his shrewd common sense, kindly geniality, and quiet benevolence will be much missed on this side of the Atlantic.

The beautiful oil painting by Sydney Hodges, a gift to the University by citizens of Montreal, in the Hall of the Museum, perpetuates his form and features to successive generations of students and graduates who enjoy the benefits of his bounty, and it is intended to place a memorial tablet in Mexican onyx in the Museum, and a bust, and also a portrait (the gift of the graduates and students), in the Library. These buildings themselves and their valuable and instructive contents will, it is hoped, constitute for ages to come the proper monuments of a man of whom Canada should be proud--a man who, in his life-time, sought neither personal honours nor distinctions, but whose name will go down to posterity as one of the true nobility of the Empire.

\section{Mitchell of California: I Pick My Rut}

\author{
by Sydney B. Mitchell
}

$\mathrm{I}$ n September, 1901, at the suggestion of my friend, his cousin, I sought and obtained an interview with Dr. Charles H. Gould, Librarian of McGill University, regarding opportunities in his profession. He encouraged me to consider librarianship as my life work and arranged for me to enter the University Library as an unpaid apprentice. I remained in the profession for forty-five years.

My previous interest in and use of this library had been wholly that of an undergraduate student. The building, an attractive one still in use, had been built in the middle 'nineties and like many libraries of the time was in a modified Romanesque style, a heritage of the influence of $\mathrm{H}$. H. Richardson, but was mercifully not constructed of the dull red sandstone popular in the period but in the grey limestone, quarried locally, which is so characteristic of Montreal buildings, even of private houses. As in a good many contemporary American libraries--the old University of Illinois and University of Michigan buildings and that of Comell University were, I believe, so arranged--the entrance was under a tower on the front, almost on a corner. There were the usual heavy oak outer doors to continually impress the seeker after knowledge in books that the way was hard; then came a vestibule and an inner set of heavy swing doors to keep out some of the cold from the reading room. Beyond these, doors to the right stairs ascended to the women's cloak-room, the faculty reading room, an exhibition gallery which overhung the reading room and was visible--and audible. Beyond it, over the stacks were some other rooms, including the law library. The men's coat-room was on the main floor to the right, and to the left was the large and attractive reading room, with stained glass windows and a lofty vaulted wood ceiling. The great amount of unusable overhead space enclosed worried later librarians, less concerned with impressiveness than 


\section{Celebrating Peter Redpath and His Library}

with their need of seating capacity. Dr. Gerhard Lomer told me that during his administration the possibility of erecting a floor above the original one was considered, something like the two-level stages of early melodramas like "The Lights of London." Practically this was possible--in fact I saw it done at the University of Pennsylvania, I believe--but aesthetically it was too much even for my practical mind. It is, however, noticeable that it has taken most architects of university and college libraries half a century to realize that libraries are functional buildings and that lower ceilings can still be sightly, less expensive, and better for artificial lighting.

The walls around the reading room were shelved with books of a reference or cultural character, but those nearest the door were, of malice aforethought, devoted to the current publications of learned societies and to journals in general of little interst to the undergraduates. The adjacent, often drafty tables, currently referred to as the mourners' benches, werc resorted to mainly by the faculty and by stuctents watching for the exit of women students with whom they proposed to walk home. By custom the men students used all the north side tables and an established number of those on the south or inner side, but no $\because$ ooden fence had been erected to divide the sexes as at the University of Toronto Library of that time. On the outer comers of this room were well lighted excrescences something like glorified bay windows, with built-in, uncushioned seats covering the hot water vines: These were too cold when the library furnace was not operating and too warm when it was going strong. There was also in the western wall an alcove and fake fireplace with cushioned seats and upholstered chairs, an early provision for sleepy students later taken over and developed into the luxuriously furnished browsing rooms of the 'twenties and 'thirties. The oak tables were equipped with green glass reading lamps, an early realistic acknowledgment of the ineffectiveness of overhead lighting in rooms whose lofty ceilings were derived from church or palace architecture. This table lighting was pretty good for those days, or maybe my eyes were just better.

The loan desk was in the south-west corner just opposite the entrance, and access to it did not involve tramping through the reading room, as the end between it and the door was free space. The catalog room and administration offices were still farther to the west and separated from the reading room by a wall into which the cabinets of the card catalog had been built so that the drawers could be withdrawn by the public in the reading room or by the catalogers on the other side of the partition. By the simple device of a pear-shaped metal drop between the drawers, irritated or overvigorous public users of the catalog were prevented from hurling them through onto the floor or the catalogers inside, yet by turning this catch to a horizontal position, drawers could be readily withdrawn into the workroom for consultation. Catalogers were not only genteel but gentle, and could be depended on to replace the drawers without danger to the unprotected public. I still think that, in a college library where the catalog will be unlikely to outgrow available space, this is a good arrangement, efficient in time saving and frankly conducive to the desire of many catalogers to remain seated.

The loan desk, a quarter segment of an ellipse, was open on the side nearest the catalog but from the space behind it a door to the west led to the workroom and right ahead was the entrance to the book stack. This five story affair was shut off by a heavy iron door, for fireproofing, I presume, but because of its weight it was often left open to the cold winds from the lowertemperatured stack area. The original structure had been equipped with steel stacks with oak shelves which sometimes sagged, like human beings, with the load of years. The metal floors in this section were gridiron, and admirably fitted to remove mud from the soles of visitors shoes, which naturally soon dried and became dust. When I was later in charge of the loan desk a collie dog which always accompanied a bachelor member of the English department to the library one day managed to slip into this stack after him. Soon after he lost his master and became petrified with fear when he found that he could look down through this footing. I was nearly as badly scared, as it devolved on me to carry him out of what he obviously regarded as an untenable position. A decade or so after the building was completed an addition to the stack was made, with steel shelving and those clouded glass floors which were so unpleasant to walk on and so distrusted by the consciously modest. Precursors of the carrels were the alcoves on each floor of the new stack, very pleasant places to study in or view the activities of the adjacent McTavish Street hill. Here, on snowy winter 
days, young girls learning to ski could be expected to take a header when they hit the intersection of the lane opposite the windows. As an honor student I had free access to the stack in my junior and senior years, and as I got all my service for myself I had no real knowledge of the machinery or the professional personnel of a college library.

As a student I knew only one member of the staff. Henry Mott had been the Librarian of McGill when it was a much smaller institution. Like others who drifted into libraries in the early days, he had not been particularly successful in business and had been glad to have a nice genteel job for which no professional training was then necessary. His main assets were a reputation as a bookman, a retentive memory and a fine bump of location, quite impressive manners--a bit patronizing to men students and sweet to young ladies-and above all a long white beard, for all of which he was paid one thousand dollars a year. When in the course of time a large library was erected and more came to be required of the librarian, Dr. Gould had been appointed to the headship and Mr. Mott became Assistant Librarian in charge of the reading room, where perhaps his most difficult task was in maintaining what he considered decorum among the cruder men students. Other tasks were to direct readers to the open shelves, get books for those who had no access to the stacks, maintain a charging system of great simplicity and very little effectiveness, and see that all who used the library signed the large register at the loan desk on every occasion of their entering the building. He was reputed among the men to play favorites in keeping desired books for selected women students, and my wife tells me that he always remembered the given names of the girls who were frequent library users and used to refer sentimentally to those having the names of flowers-hers was Rose--as being in his "garden of posies.'

\section{City of Manchester Libraries Committee Report of a Visit to Libraries in the United States and Canada by Representatives of the Committee: Libraries in Canada}

\author{
by City of Manchester Libraries Committee
}

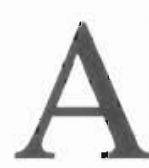

$t$ Toronto we had the advantage of the guidance of Mr. W. J. T. Lee, a member of the Board of Management, and of Mr. C. E. Ryerson, assistant librarian. The Public Library was opened in 1883 through the exertions of the late Alderman Hallam, a native of Lancashire. Since then the building has become so congested that its work is now carried on under great disadvantages. This condition of things will shortly be remedied by removal to a new and spacious building, now approaching completion, at the cost of Dr. Carnegie, who has also contributed funds for providing three new branches.

The McGill University Library at Montreal is housed in the fine Romanesque buiding erected in 1893 by the late Mr. Peter Redpath.

Dignified and convenient as originally designed, it was improved and greatly enlarged in 1900 by the late Mrs. Peter Redpath. It now possesses ample accommodation for three hundred and fifty readers, of whom fully one hundred can be provided for in the seminary rooms and special studies.

The main architectural feature of the interior is the general reading room, 110 feet long, 44 feet wide, 34 feet high. It will seat one hundred and fify readers, and has open shelves for about 4,000 volumes.

The Library is available for use by citizens as well as by professors and students. It has been admirably organised by the librarian, Mr. C. H. Gould, to whom we feel particularly indebted for kindnesses extended to us on our visit to Montreal.

The book stacks are constructed of steel, and painted white. The usual ventilation openings in the gangways have their openings in the centre instead of at the sides, thus preventing dust from settling on the volumes underneath. Each floor of the stack is provided with 
recesses or tables for private study. There are cabinets ingeniously constructed for large maps and plates.

The drawers containing the card catalogues are so arranged as to form a screen between the readers and the cataloguing staff, and, opening on either side, are available for use both by the staff and the readers, thus avoiding the necessity for a separate official set of cards.

This Library has an extensive system of travelling libraries, boxes of books being sent on request to any part of Canada. The entire cost of this valuable work is borne by members of the McLennan family, who have in many ways benefited the Library.

A Library School, which forms part of the regular curriculum of McGill University, and a Summer School for librarians, are carried on under the direction of $\mathrm{Mr}$. Gould. The summer course extends over four weeks, seven hours daily, and the teaching is adapted to persons without previous experience who may contemplate entering upon a library career, but it is required that all candidates should have previously acquired a good general education.

We visited also the Fraser Institute at Montreal, which, though not under municipal control, serves as a Free Public Library for the city. It contains 70,000 volumes.

At Westmount, a suburb of Montreal, we inspected a small but exceedingly attractive public library, which has recently been erected.

We visited the Parliament Buildings at Quebec, which contain a valuable library, housed in a large and handsome suite of rooms. It is chiefly intended for the use of officials and members of the Legislature.

The largest library in the city is that of the Laval University. It consists of 150,000 volumes, and is rich in works relating to Canada. The Quebec Literary and Historical Society has another valuable collection of books on the history of the Colony.

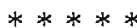

\section{The Redpath Library: Half a Century (1892-1942)}

\author{
by Gerhard R. Lomer
}

I

n the autumn of 1942 the Redpath Library will have completed half a century of service to the University and to its graduates. It is appropriate that this semi-centennial provide an occasion for looking backward at what has been accomplished during this period of its existence and for looking forward to the needs and opportunities of the future.

McGiil half a century ago was a very different institution from the great and multifarious university that it is to-day. During this period it has had seven principals, six deans in the Faculty of Arts and two librarians. In 1892 the staff of the Faculty of Arts included only fifteen professors and lecturers; the students numbered 106 men and 60 women, then called "Donaldas" in honour of Sir Donald Smith, afterwards Lord Strathcona, one of the great benefactors of the University and at that time its Chancellor.

The library, at that date, was also on a small scale. It had been housed for years in one room, at the west end of the Arts Building, on the ground floor of Molson Hall, the upper floor of which was used for the dual functions of examinations and convocation. The room had a long table for reading running down the centre, and the sides were occupied by high shelves of yellow oak forming alcoves under the windows. There was an enormous register for readers, a card catalogue showing the location of the books, and one librarian and an assistant, both of whom were men. Apparently as an encouragement to patronage, the library regulations contained the statement that "Donors of books or money to the amount of fifty dollars may at any time consult books on application to the librarian." The only persons having direct access to the books were members of the Corporation and professors.

To-day, on another part of the campus, the library is too large and its activities are too numerous to be adequately housed in a large stone building, specially constructed, with readıng rooms, work-rooms, six floors of steel stacks, a periodical room, a large card catalogue, an exhibition gallery, a museum, a library 
sch(o)l, and a book club. The congestion of the present huilding, so evident and so inconvenient of late years, has resulted in the transference of the Travelling Libraries to Macdonald College and the storage of duplicates, newspapers, and uncatalogued books in the stable of the Faculty Club and in the basement of Douglas Hall. The proposed transfer of books on Commerce and Economics to Purvis Hall this auturnn will provide only temporary alleviation. A new building is imperative or a drastic remodelling of the present one, which has now served the university community for half a century. But that is another story. We are at the moment looking backward.

Peter Redpath, as the Hon. J. A. Chapleau, then Lieutenant-Governor of the Province, said on the occasion of the opening, "donated to this great and noble university a magnificent building for a shelter for its potential knowledge," and it is by his generosity and foresight that generations of students have been benefited in their studies and encouraged to make valuable contributions to Canadian scholarship and public service. To Mrs. Peter Redpath, who added in 1900 to the original building, gratitude is aiso due, and to the many members of the Redpath family who have continued the tradition of loyalty to McGill. Among these should be mentioned Lady Roddick, Mr. John R. Redpath, and Mr. James B. Redpath. Nor would the list be complete without recording at the same time the names of Dr. Francis McLennan and Miss İsabella C. McLennan, who have done so much for the Travelling Libraries and the Museum of the Library; Dr. and Mrs. A. D. Blackader, and their friends, who donated the Blackader Library of Architecture; Dr. and Mrs. Casey A. Wood, who provided the Wood Library of Omithology; Mr. and Mrs. Robert Roe Blacker, who established the Blacker Library of Zoology; and that long line of donors, too numerous to mention by name, who, "here a little and there a little" have added to the shelves, filling in gaps and providing books that would otherwise have been unavailable to generation after generation of students. To them the University will ever be grateful, as well as to the thoughtful generosity of those who, like Dr. Helen R. Y. Reid, have bequeathed to McGill their personal collections of books. Si monumentum requiris, circumspice.

The Library has benefited for many years from gifts of books and funds made by individual graduates, but it records with particular gratitude the generous assistance provided by the income from the Sir William Dawson Memorial Fund, which was originally collected by the McGill Graduates' Society and has been administered by that body for fifty years for the benefit of the Redpath Library and the Travelling Libraries.

The early history of the Redpath Library coincided with a great period of expansion and enthusiasm in library work in the United States, and McGill was fortunate in having as its librarian, Charles H. Gould, (B.A., 1877), one of her own graduates, whose active interest in library development in Canada was evidenced not only in his effective administration of the Redpath Library but by his establishment of the first Travelling Library system in Canada and the first Library School in Canada. The former, endowed and supported by members of the McLennan family, has brought education and entertainment into isolated communities throughout Canada from British Columbia in the West to Labrador and Newfoundland in the East. Of late years, as its functions have been properly filled by the creation of local agencies, its activities have been concentrated in the Province of Quebec, in the encouragement of school libraries and in the bookpool of the Eastern Townships.

The Library School, begun as a summer course in 1904, became a year course in 1927 and in 1931 granted the first B.L.S. degree in Canada. It now has graduates in all the provinces of Canada, in Government libraries in Ottawa, in most of the special libraries in Montreal, and in some of the best-known libraries in the United States. It has published useful bibliographies, and members of its staff have gone to better teaching and administrative positions in library schools and colleges in the United States. For support, encouragement, and advice, the Library School owes to the Carnegie Corporation and to Miss Sarah C. N. Bogle, of the Board of Education for Librarianship, a debt which it gratefully acknowledges but can never repay.

But Mr, Gould's work was not confined to Travelling Libraries or library instruction. He began a system of scholarly cataloguing that has been the basis of all our later work; he established and administered the Canadian Bureau of the International Catalogue of Scientific Literature; he arranged for the local 
depository catalogue of the Library of Congress; and he took such an active part in the work of the American Library Association that he was honoured by election as its president in 1908-1909. His untimely death in 1919 left to his successor an admirably organized library, a number of projects to be completed, and the professional inspiration of a scholarly gentleman devoted to the collection, arrangement, and intelligent use of good books.

The story of the Library during the decade beginning 1920, when the present librarian was appointed, has already been told in The MCGILL N'Ews (V. 2. No. 4. Sept., 1930) and therefore needs only a brief summary here. As was pointed out in 1930, ten years before that date there had been no Library Museum or series of exhibits, no sessional library course, no Wood Library of Ornithology, no Blacker Library of Zoology, no Gest Chinese Research Library, no Periodical Room, no Catalogue of Scientific Periodicals in Canadian Libraries, no organization of Departmental Libraries, no Freshman reading-room, and no Bindery. The value of these improvements to the Redpath Library was reflected in the statistics of the use made of the building. The number of readers increased from 30,454 in 1920 to 83,777 in 1929, and the circulation of 27,649 in 1920 increased to 107,466 in 1929. Since that date the figures reached a peak of 139,384 readers in $1935-36$ and a circulation of 197,037 books in 1941-42.

During all these years the Librarian had the sympathetic support of a Committee, of which Sir Arthur Currie was an active Chairman, and whicl included such experienced and far-sighted men as Sir Thomas Roddick, Dr. William Gardner, Professor Paul T. Lafleur, Mr. C. J. Fleet, Dr. R. F. Ruttan, Dr. Francis Mclennan, Dr. C. W. Colby, Dr. C. F. Martin, Dr. F. D. Adams, Dr. W. D. Lighthall, Dr. A. S. Eve, Dr. C. E. Fryer, Professor G. W. Latham, Dr. D. L. Ritchie, Dr. W. M. Birks, Dr. W. G. M. Byers, and Mr. F. Cleveland Morgan. This Committee properly regarded itself as advisory and devoted much of its energy to obtaining donations for the Library--a function to which committees subsequent to Sir Arthur's death paid little attention. In fact, under Principal $A$. Eustace Morgan and Principal Lewis W. Douglas, the committee tended to exaggerate its adminstrative function. So true, however, is the saying that "Too many cooks spoil the broth" that the danger of committee interference in library administration was emphasized in a recent work on the college library which referred as follows to the exercise of adminstrative control by a so-called "Library Committee of the Faculty":

This designation of administrative authority seldom fails to have a seriously harmful effect upon the library. To the librarian, without interference and meddling, however well-intentioned, belongs the adminstration of the library. The special training required for the exercise of the function is considerable. It is folly of the worst sort to endanger the results by making the decisions and activities of the librarian subservient to a committee of the faculty who may render futile his best efforts. ${ }^{2}$

Disregard of this principal of administration usually results in clual control, unnecessary red tape, departmental politics, confusion in library routines, and economic waste in not utilising to the full the professional experience and training of the librarian.

Most of the activities of this period noted above have been continued and developed, with the exception of the Gest Chinese Research Library which, under the able and expert supervision of Dr. Nancy Lee Swann, had done admirable and widely-known reference work. Contrary to the advice of the Librarian, this library, which was indubitably the second-best and in some respects the best on the continent, was removed by Principal A. E. Morgan under circumstances which evoked unsympathetic comment in academic circles in the United States.

There were fortunately brighter sides to the Library during this period. Under the able direction of Dr. C. F. Wylde, and his successor, Dr. R. L. Stehle, the Medical Library made great strides forward in acquiring and cataloging new material and in the disposal of duplicates. The outstanding event, however, was the arrival in 1928 of the Bibliotheca Osleriana, and its singularly appropriate curator, Dr. W. W. Francis. This collection, as noted in its large and erudite catalogue, represents one important aspect of the 
life work of Sir William Osler and will be an enduring testimony to his sympathetic interest in the development of science. Dr. Frank D. Adams' recent (1942) gift of his collection of books on early science is a welcome supplement and adds considerably to the completeness and value of this department of the Library.

A second notable addition to the resources of the Library was the establishment of the Carnegie Library, in 1933, under a grant from the Carnegie Corporation, specifying its particular field as that of free cultural reading for undergraduates. Under the direction of a sub-committee, a fine and well-balanced collection of books has been provided, at present very inadequately housed in the Arts Building, but carefully kept up-todate by a conservative use of the funds. The provision of adequate quarters for this admirable collection offers an opportunity to some graduate grateful to his Alma Mater for benefits received.

In addition to these special collections, the needs of teaching staff and students on various parts of an extended campus are supplied by the special libraries in the Engineering, Chemistry, and Physics Buildings, by the small libraries in Biology and the Redpath Museum, and by the inadequately housed Law Library.

The increasing interest of students in the Library has led to the provision of numerous conducted tours during the opening weeks of each session, often "every hour on the hour," to make new students familiar with the arrangement of the building, the use of its catalogue and reference books, and the services available. There would be a distinct gain to students and professors alike if all newcomers were required to take these tours or, better still, if elementary instruction in the use of the library and its books were made a required part of the Freshman course.

The backwardness of Montreal, compared with Toronto or Vancouver, in providing adequate library service for its citizens, led to the formation of two hook clubs associated with the Redpath Library. The Mcuill College Book Club, no longer extant but situated for many years in a local book-store, gave annually a number of valuable books to the Library. The University Book Club, self-supporting and housed in the Redpath Library, supplies both staff and a limited public with books of the current year and gives to the
Library the books which it withdraws from circulation. There is, however, a crying need for a predominantly English public library situated in the residential district between University Street and Atwater Avenue.

The interests of the community, as well as those of students, are served in part by the provision in the Redpath Library, during a score of years, of exhibits of books, manuscripts and pictures relating to topics of current interest or of cultural value in connection with the regular subjects of instruction. The Library Museum is arranged to illustrate the development of the arts of record and the history of the book through the ages as an appropriate background to the contents of the Library and as an attempt at their graphic correlation for educational purposes. Thanks to such generous donors as Lady Roddick, Dr. Francis McLennan, F. Cleveland Morgan, Howard Murray, and others, the Library Museum has so increased in the value of its collections that it has contributed by request to such exhibitions as that on Persian Art held in Burlington House, London in 1931, and in the De Young Memorial Museum at San Francisco in 1937. The small case at the Library entrance has given opportunity to the students of the Faculty of Arts and of the Library School to arrange exhibits of particular interest to themselves. As a precaution against possible air-raids, in pursuance of the University policy of safe-guarding its most valuable possessions, much of the Museum material has been temporarily stored in a specially constructed room in the basement.

The war has also had an effect upon periodicals, as all magazines from enemy countries have ceased to arrive, and efforts to obtain these through government channels have thus far not been successful. It is to be hoped, however, that the same means that filled up gaps after the last war will be similarly successful when peace is again assured.

In other ways, also, the war has affected the activities of the Library. Nine members of the staff have been working all winter with the McGill or other Chapters of the Red Cross; three members of the staff have taken the St. John's Ambulance Course; the Librarian has acted as Warden for the Library in blackouts and practice evacuations of the building, and is Librarian for Military Districts 4 and 5 in supervising the distribution of educational books to aviation centres 
and training camps under the Educational Services of the Canadian Legion. Thus far, a total of 7,656 books have been sent to 53 training centres.

No account of the Redpath Library would be complete without some word of grateful recognition of the efficient and self-sacrificing work of a staff which, in spite of all representations, has an inadequate salary scale, no academic status similar to that customary in the United States, and is too small for the size of the institution it serves. In particular, gratitude is due, for long and efficient service, to Miss Margaret Mackay, who helped install the Redpath Library, served as Head Cataloguer, and was in charge of the International Catalogue of Scientific Literature until her retirement in 1925; to Miss Jean Cameron, for many years AssistantLibrarian of the Medical Library; to Miss Elizabeth G. Hall (B.A. McGill 91), who, with sympathy and energy, administered the Travelling Libraries for thirtyfive years; and to Miss Laura A. Young (B.A. McGill '97), who retired in 1940 as Head of the Circulation and Reference Department after thirty-three years of friendly and helpful service. Others, too numerous to mention, have also spent years in the Library and have made valuable contributions to its daily routine and to its progress.

Members of the staff have also taken an active part in professional progress. The Quebec Library Association was established through the energy of the staff and has had as president, Miss Laura A. Young, Miss Helen L. Haultain, and Miss Margaret E. Hibbard, and the Librarian, who was subsequently appointed Honourary President for life. Relations with the American Library Association have been close and cordial: members of the staff have served on its Council and committees, and all members of the staff served on local committees when, in 1934, the Association held its annual conference in Montreal. The Librarian is also a member of the newly established Canadian Library Council and is a Fellow of the Library Association (of Great Britain). The graduates of the Library School are carrying on this tradition of service and are contributing, in many Provinces and States, to professional advancement and to the good name of McGill. Experience on the staff of the Redpath Library, and the Library School in particular, has proven that McGill is a good stepping-stone to professional service elsewhere. Mrs. Mary Duncan
Carter later became Director of the Library School of the University of Southern California; Miss Doris A. Lomer was appointed Librarian of Sweet Briar College, Virginia, a position now occupied by Miss Janet Agnew; Miss Nora Bateson established a provincial library system in Prince Edward Island and in Nova Scotia; Mr. R. M. Hamilton joined the Library of Parliament in Ottawa; and Miss M. E. Gore, the Okanagan Valley Union Library at Kelowna, B.C.

The graduates of McGill, fifty classes of them in steady sequence through half a century, will look back upon the Redpath Library with gratitude to Peter Redpath, Mrs. Redpath, and members of the Redpath family, for the foundation and support of the Library. What will the graduates of the next half-century look forward to as they come as Freshmen or look back upon after graduation?

It is no secret that the present building can do no more than any other college library. No other college library building in a live institution has an indefinitely long life. Ideals change, students increase in numbers, methods of teaching alter, book collections grow, and library techniques improve. With these the college library must keep pace. The Redpath Library building is no longer adequate for its readers or its books, so greatly has McGill grown and changed in fifty years. As was noted in the Annual Report of the Library for 1939-40:

With its reading-rooms so overcrowded that there is provision for only 6.93 per cent of the registered students, with entirely insufficient space for graduate students and teaching staff or the books that they use, with a library staff so reduced in numbers that it cannot properly meet the present demands made upon it and so overworked that physical breakdowns have recently resulted, and with Redpath Library funds that this year are $\$ 27,954$ less than those provided in 1931-32, when the total amount, even at that date, was lamentably insufficient to fill the gaps left in earlier days or to keep abreast of modern publications--with all these conditions to cope with, the Library cannot be expected to fulfil the functions 
it is eager to put into operation. There can be no doubt in the minds of those who realize the gravity of the situation that, if these conditions are allowed to persist, the Library, as well as the rest of the University, will stagnate and fall behind in the general educational progress of Canada.

The picture is not entirely a gloomy one, however. During the new régime of Principal F. Cyril James, whose intimate association with other libraries makes him sympathetic to the needs of McGill, it is to be hoped that the present inadequate facilities will be improved as soon as the cessation of war renders it possible. A beginning has already been made in the establishment of a library in Purvis Hall to be a centre for books on Commerce, Law, and Public Administration.

In conclusion, what was written in 1930 still holds so true that it deserves to be repeated:

What of the future? The growth of the Library is bound up with that of the University as a whole. No great university can thrive without a great library. The collecting of books, however, is not an end in itself, nor the aim of a university; rather, the knowledge of how to use books and the habit of using them effectively are two fundamental aims of higher education. No technical training can be acquired and no professional skill can be developed without books as a foundation and background, or as instruments.

To curtail the Library--in space, staff, equipment, or books--is to limit the true activity of the University as a whole, for the Library is not a department but a service, as truly and essentially as are light, heat, and power. The University is the leader, pioneer, and foreseer of things to come in the intellectual life of the community. As such it transfers into the life of the city and the countryside the intellectual light, the emotional glow, and the effective productive power that lie latent in books, until students are wisely taught to transform this energy into their daily life among men. From this point of view, the University Library becomes one of the great instruments of public service-great in possibilities and, when properly administered and wisely used, great in achievement. 


\section{Notes}

The editors would like to thank especially Tom Humphry and Anette McConnell of the Notman Photographic Archives, McCord Museum of Canadian History, and Phebe Chartrand, Archivist, McGill University Archives, for their valuable assistance in preparing the photographic section of this article.

Dawson, John William (1820-1899). Born in Pictou, Nova Scotia, Dawson became Principal of McGill in 1855. Educated in Nova Scotia and in Edinburgh, Dawson was one of Canada's leading nineteenth-century scientists, particularly in the areas of geology and palaeontology. He was also a vigourous opponent of Darwinism. It was during Dawson's principalship that McGill began to develop into a major university and benefactors such as Peter Redpath played an important part in this development. Dawson was knighted in 1884. "In Memoriam: Peter Redpath" is reprinted from John William Dawson, In Memoriam, Peter Redpath: Governor and Benefactor of McGill University and Founder of the Museum, Library and Chair of Mathematics which bear his name (Montreal: For the University, 1894), 5-16.

Mitchell, Sydney Bancroft (1878-1951). Born in Montreal, Mitchell worked in the Redpath Library as a student, and then as a cataloguer for four years. Because he had a congenital hip dislocation, the Library at first was reluctant to hire him, but when he set a record for climbing the stack staircase from bottom to top and back again, his disability was forgotten. In 1908 Mitchell moved to California working first in the Stanford University Library, and then for the rest of his career at the University of California Library, Berkeley. In addition to his library work, Mitchell was a well-known gardener and widely on horticultural subjects. "Mitchell of California: I Pick My Rut" is reprinted, by permission from Sydney B. Mitchell, Mitchell of California (Berkeley: California Library Association, 1960), 97-101.

Manchester Libraries Committee. The City of Manchester was planning to erect a new civic building on the site of the Manchester Royal Infirmary. This building would include a library and art gallery. In preparation for the new building, the Libraries
Committee, on 29 January 1908, passed this resolution: That the Chairman, Deputy-Chairman and Chief Librarian be authorized to inspect such libraries at home and abroad as the Committee may consider desirable for the purpose of obtaining information for the guidance of the Committee in view of the provision of the New Reference Library.

Libraries were visited in London, Oxford and Bristol. On 4 April the Chairman, Deputy-Chairman and Chief Librarian left England for a six weeks tour of libraries in eastern North America including those in New York, Albany, Boston, Philadelphia, Washington, Chicago and Pittsburgh, and those in Toronto, Montreal and Quebec City. The "Report" of the City of Manchester Libraries Committee appears in Report of a Visit to Libraries in the United States and Canada by Representatives of the Committee (Manchester, 1908), 30-32.

Lomer, Gerhard R. (1882-1970). Lomer was born in Montreal and educated at McGill (B.A. 1903, M.A. 1904). In 1910 he received a Ph.D. in Education from Columbia University. In 1920 he returned to McGill as University Librarian, a position he held until 1947. During Lomer's tenure as University Librarian, many important books and collections were added to the Library and this despite the severe financial problems of the 1930s. Lomer was a leader in Canadian library education, and after his retirement in 1947 he taught until his death in the Library School of the University Ottawa. Gerhard R. Lomer's article "The Redpath Library: Half a Century" is reprinted from The McGill News (Autumn 1942), 9-13.

Most of the photographs have been provided by the Notman Photographic Archives, McCord Museum of Canadian History, and the McGill University Archives.

1. Subsequently, by permission of Mr. Redpath, transferred to the subject of Mathematics.

2. Randall, W. M. and Goodrich, F. L. D.: Principles of college library administration. Chi. 1941. 2 ed. p. 86. 


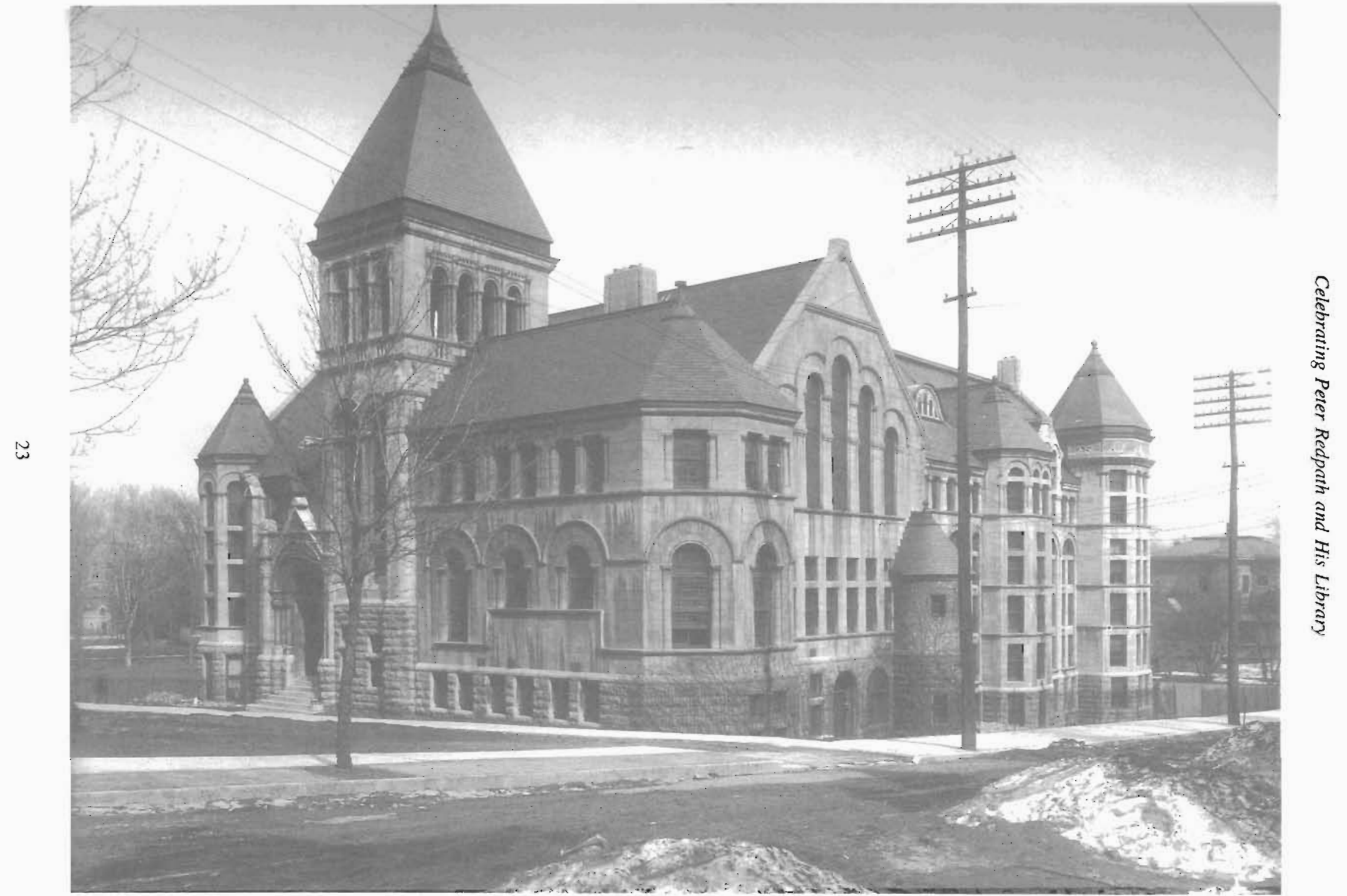

Redpath Library from McTavish Street showing the addition (on the right) built by Mrs. Peter Redpath, 1901. (Notman Photographic Archives, McCord Museum of Canadian History) 
Celebrating Peter Redpath and His Library

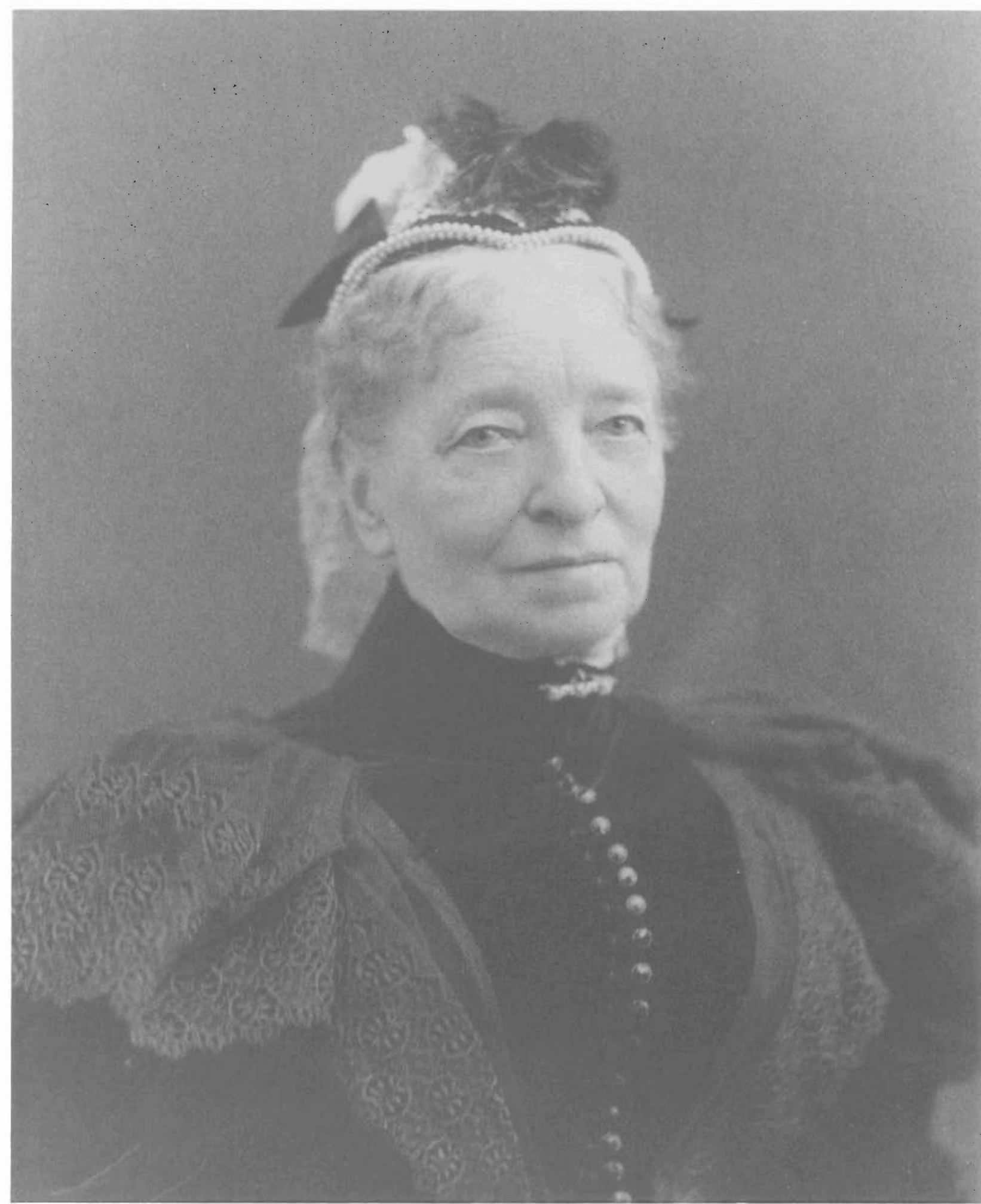

Grace Redpath, ca. 1900. (Department of Rare Books and Special Collections, McGill University Libraries) 
Celebrating Peter Redpath and His Library

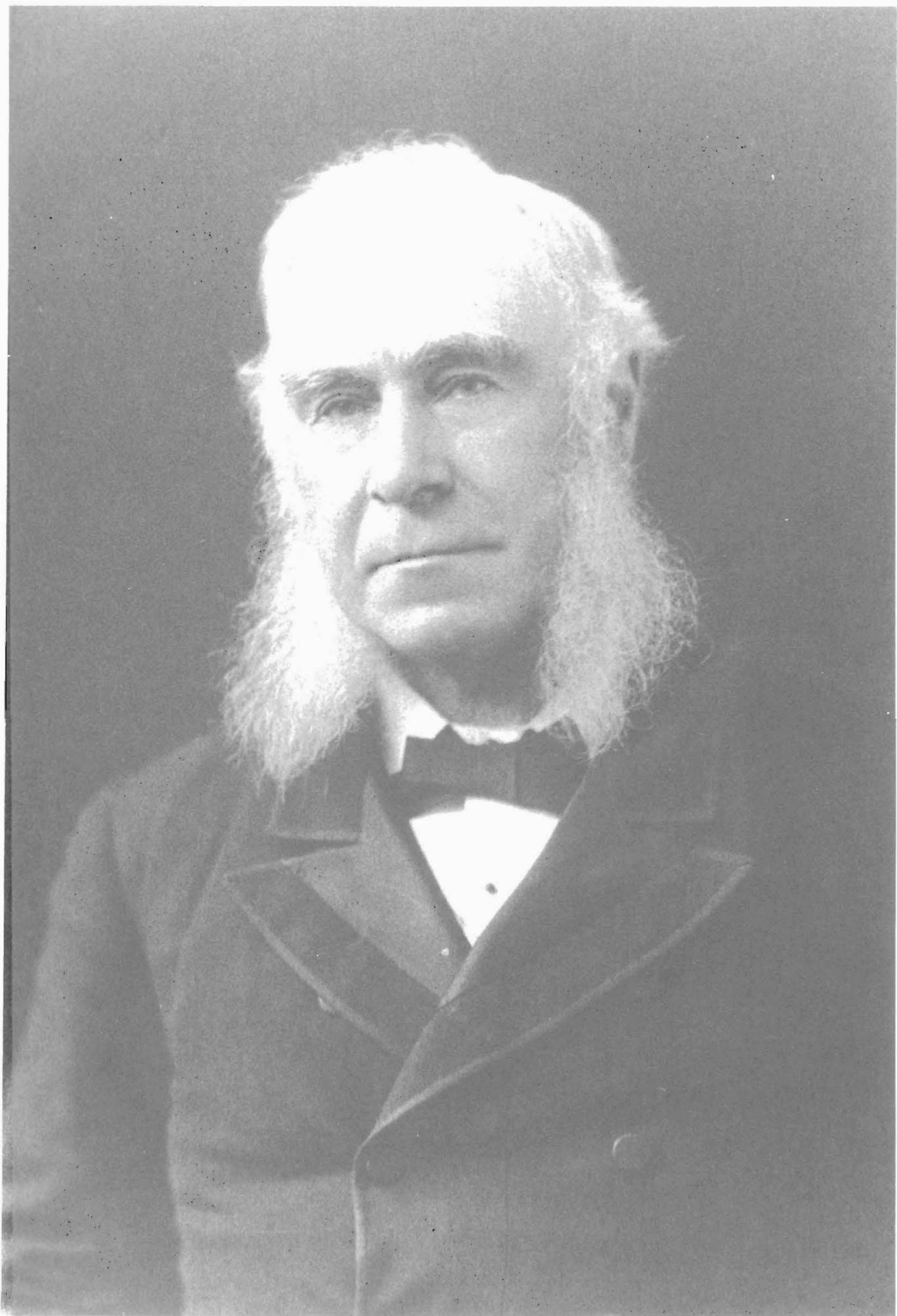

Peter Redpaith, ca. 1893. (Department of Rare Books and Special Collections, McGill University Libraries) 


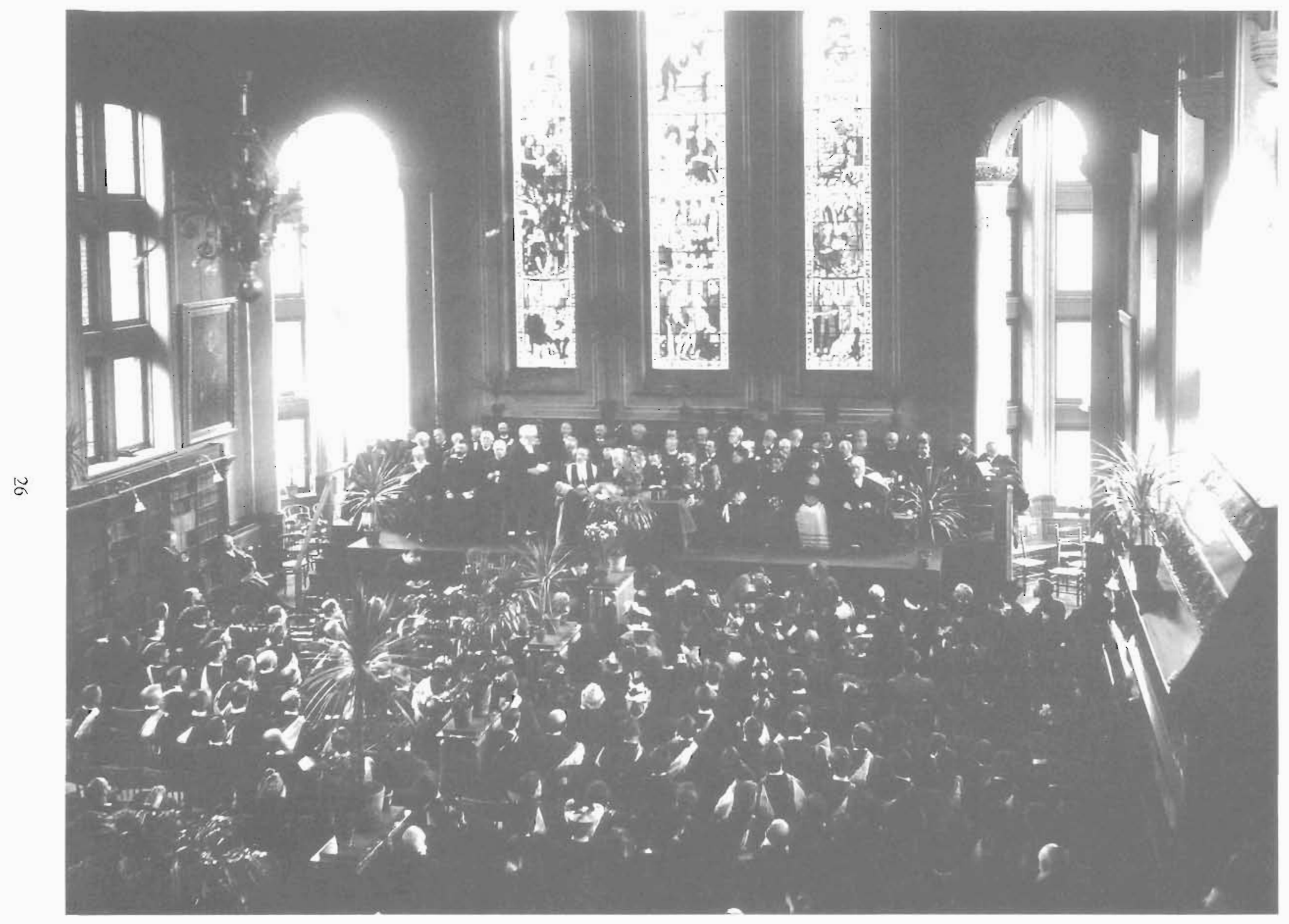
Countess of Aberdeen and Mrs. Redpath. (Notman Photographic Archives, McCord Museum of Canadian History) 


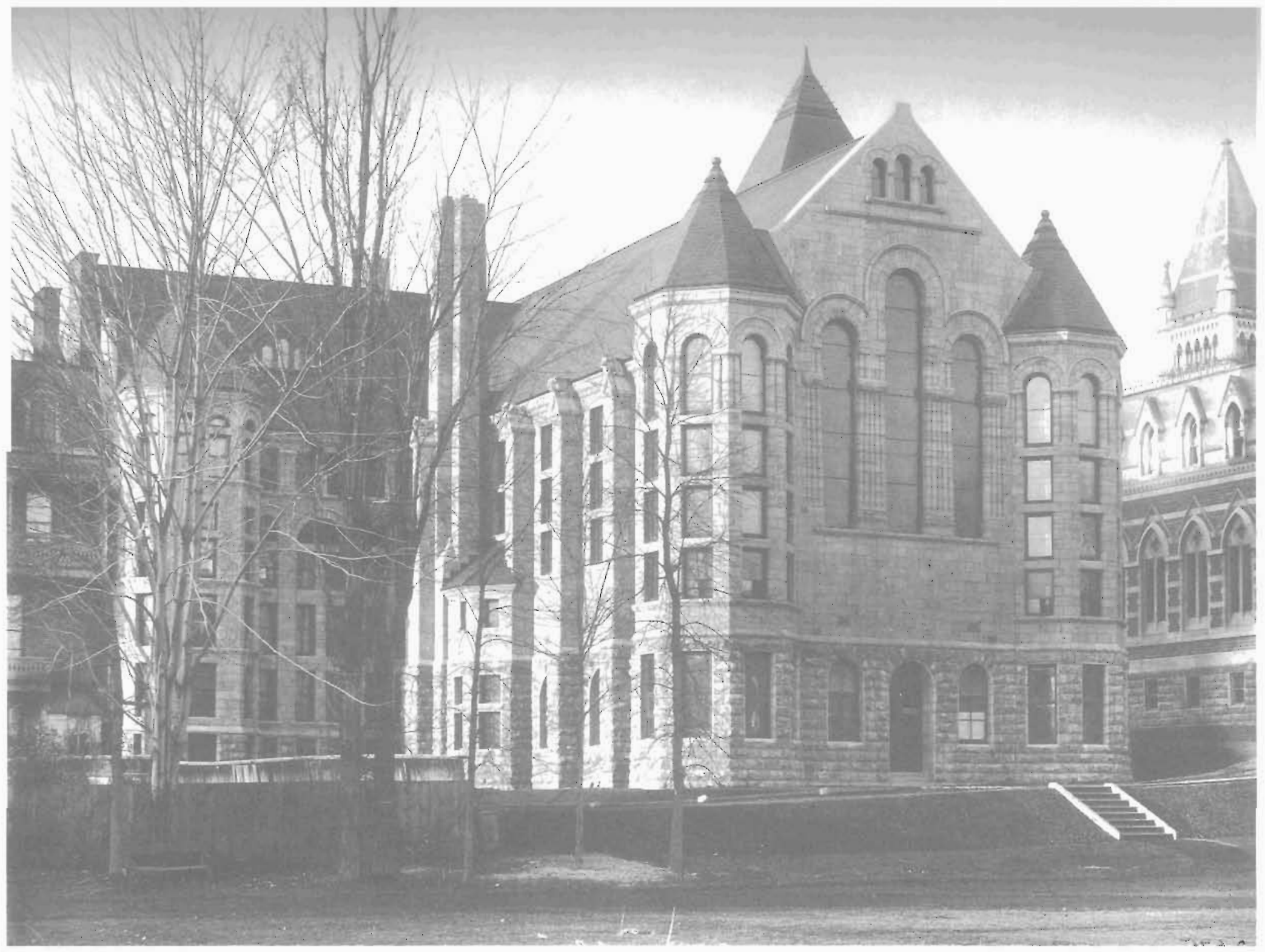

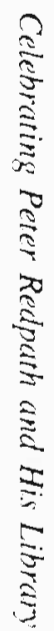

Redpath Library from the Campus, showing the original building of 1893. (Notman Photographic Archives, McCord Museum of Canadian History) 


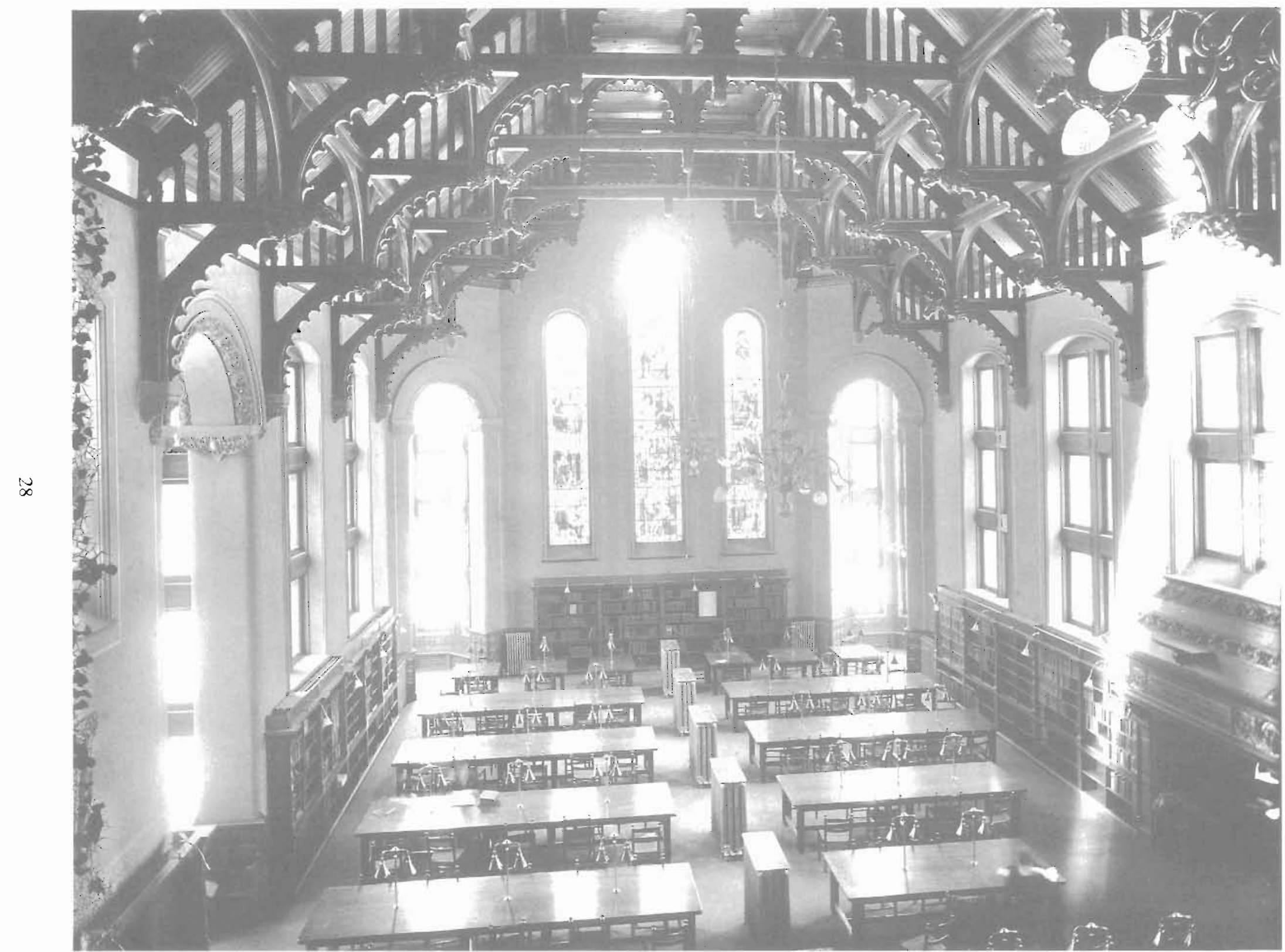




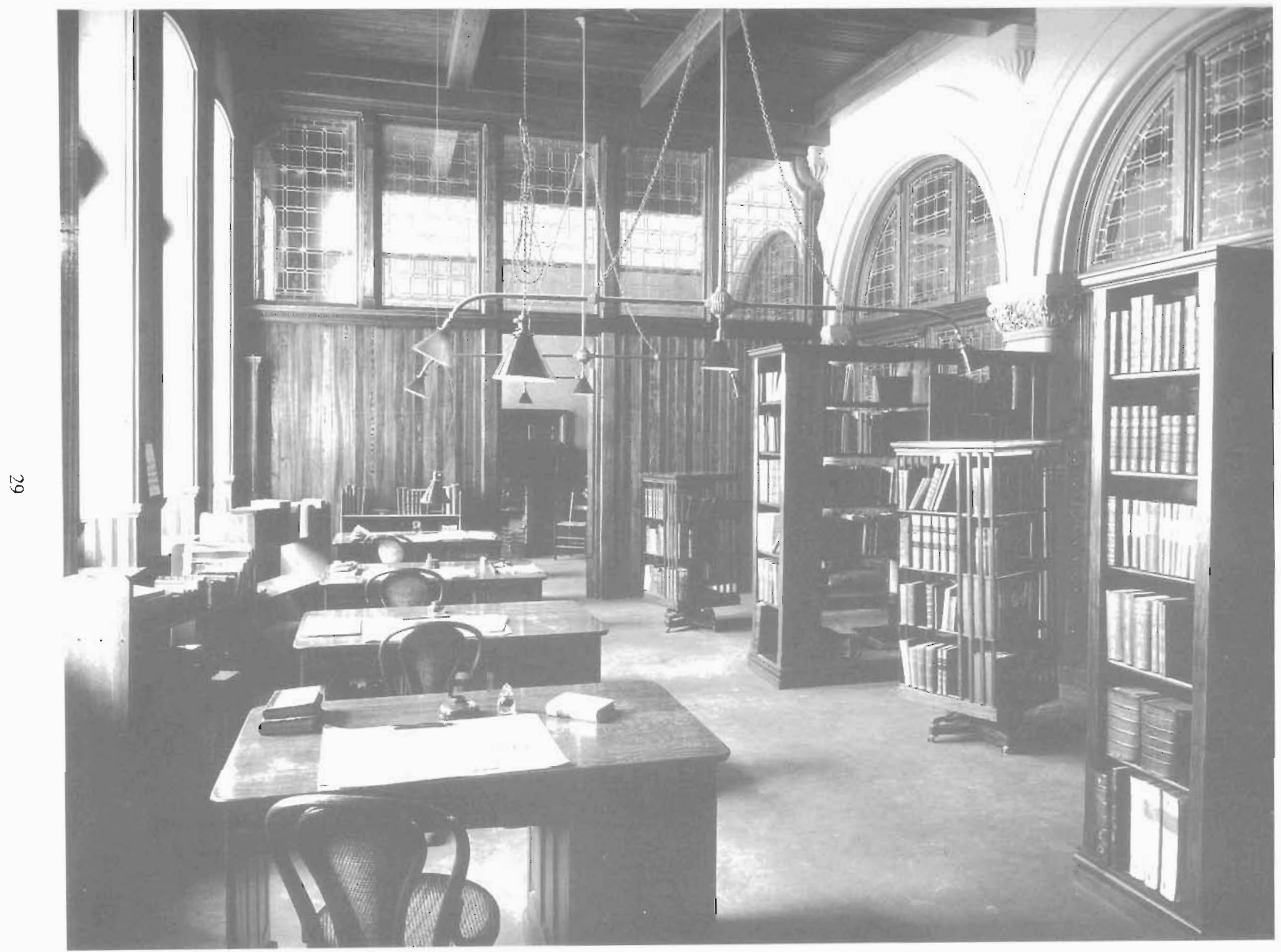

Cataloguing Room, Redpath Library, 1893. (Notman Photographic Archives, McCord Museum of Canadian History) 
Celebrating Peter Redpath and His Library

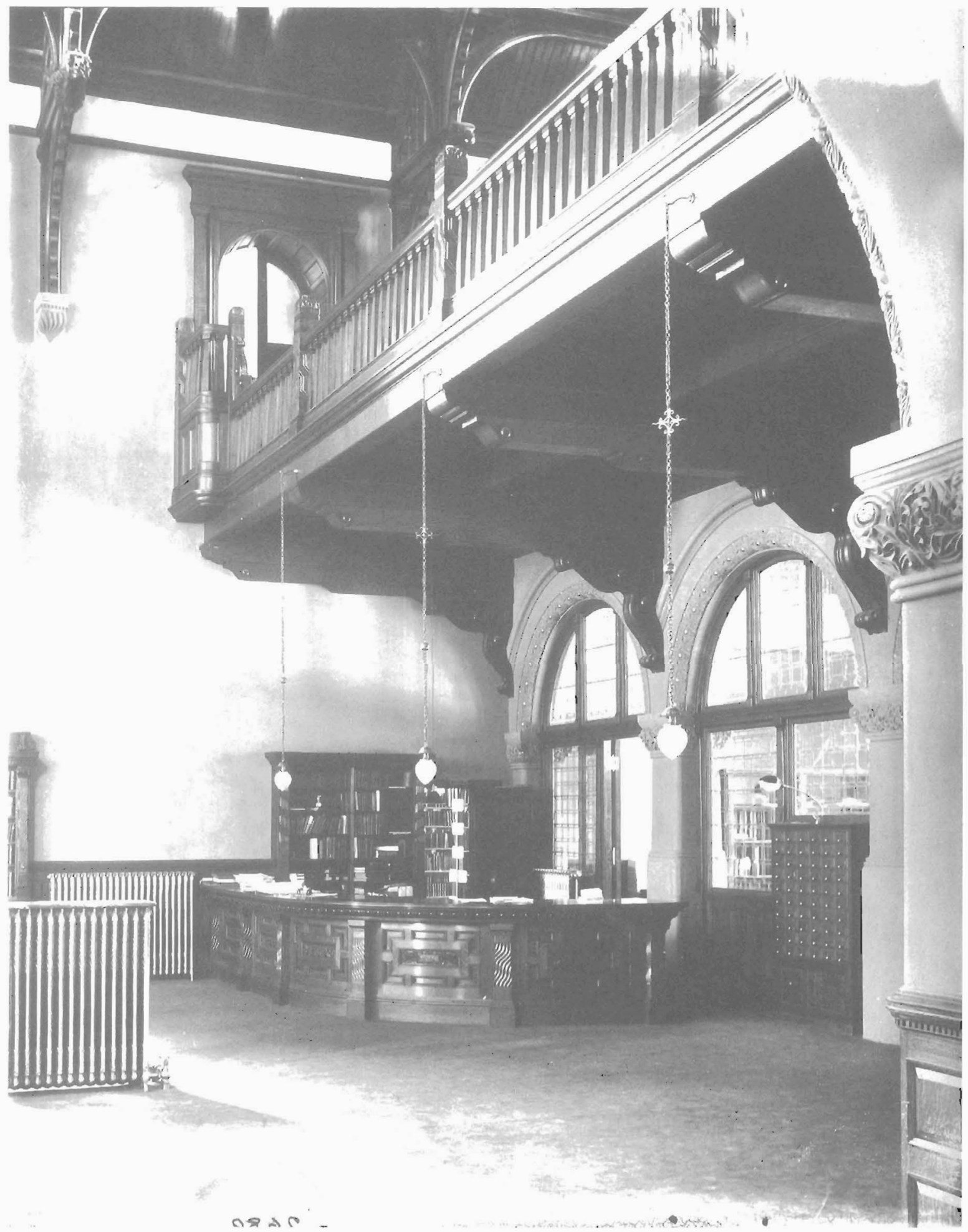

Delivery Counter, Redpath Library, 1893. (Notman Photographic Archives, McCord Museum of Canadian History) 


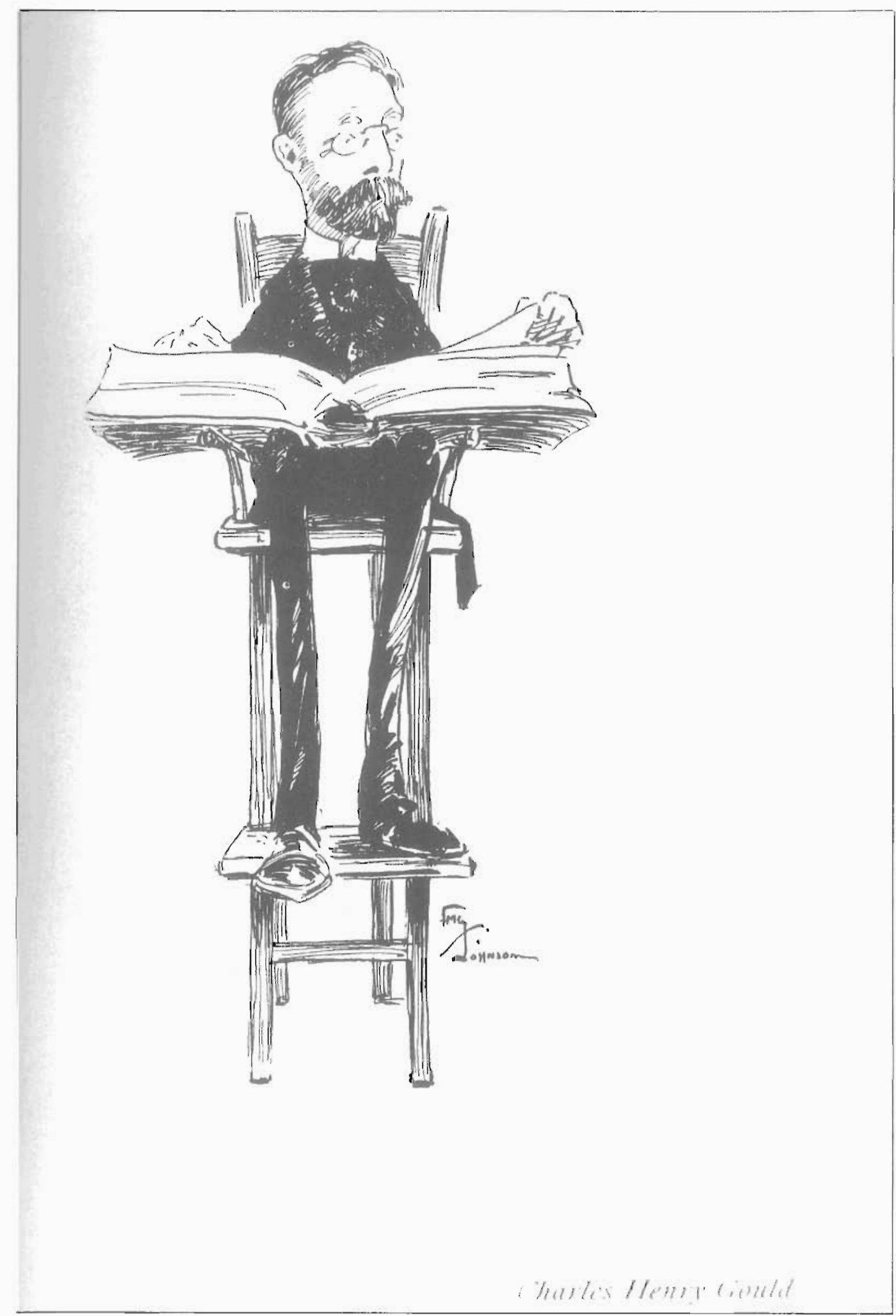

The University Librarian. (F.M.G. Johnston, People We Meet, Montreal: McGill Outlook, 1903) 


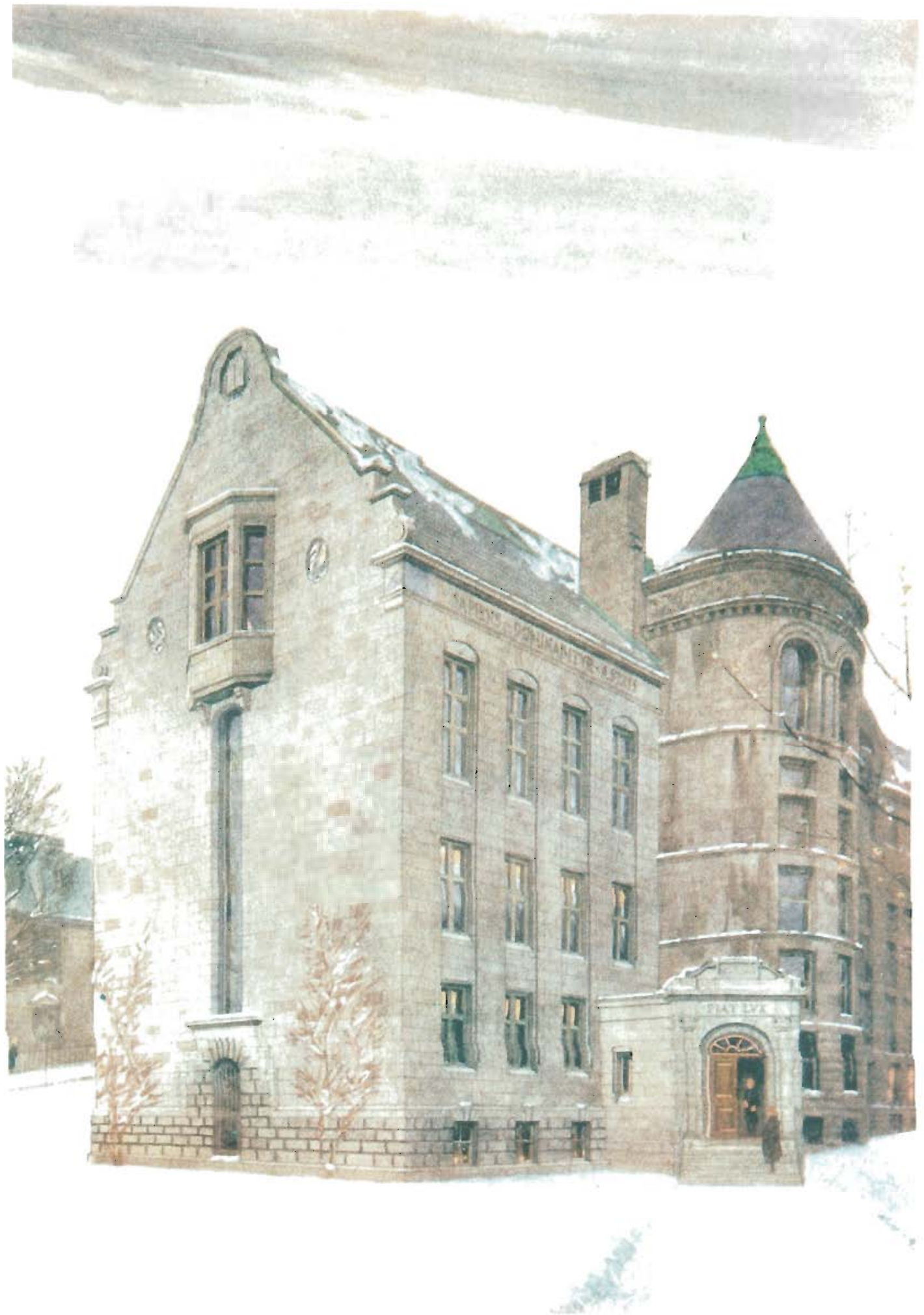

The 1921 addition by Percy Nobbs to the Redpath Library. (Old McGill, 1923) 
Celebrating Peter Redpath and His Library

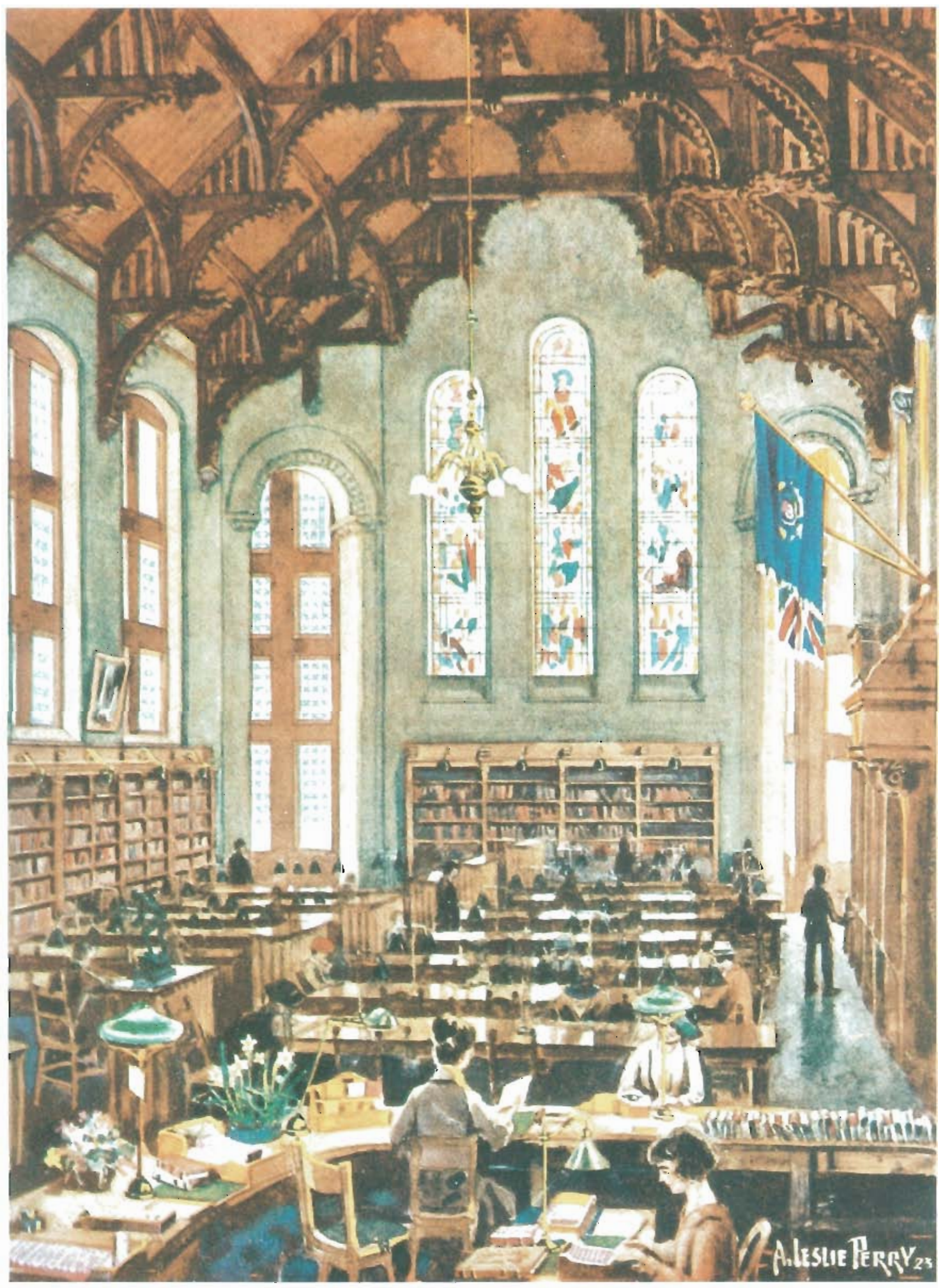

Reading Room, Redpath Library by A. Leslie Perry, 1923. (Oid McGill, 1924) 


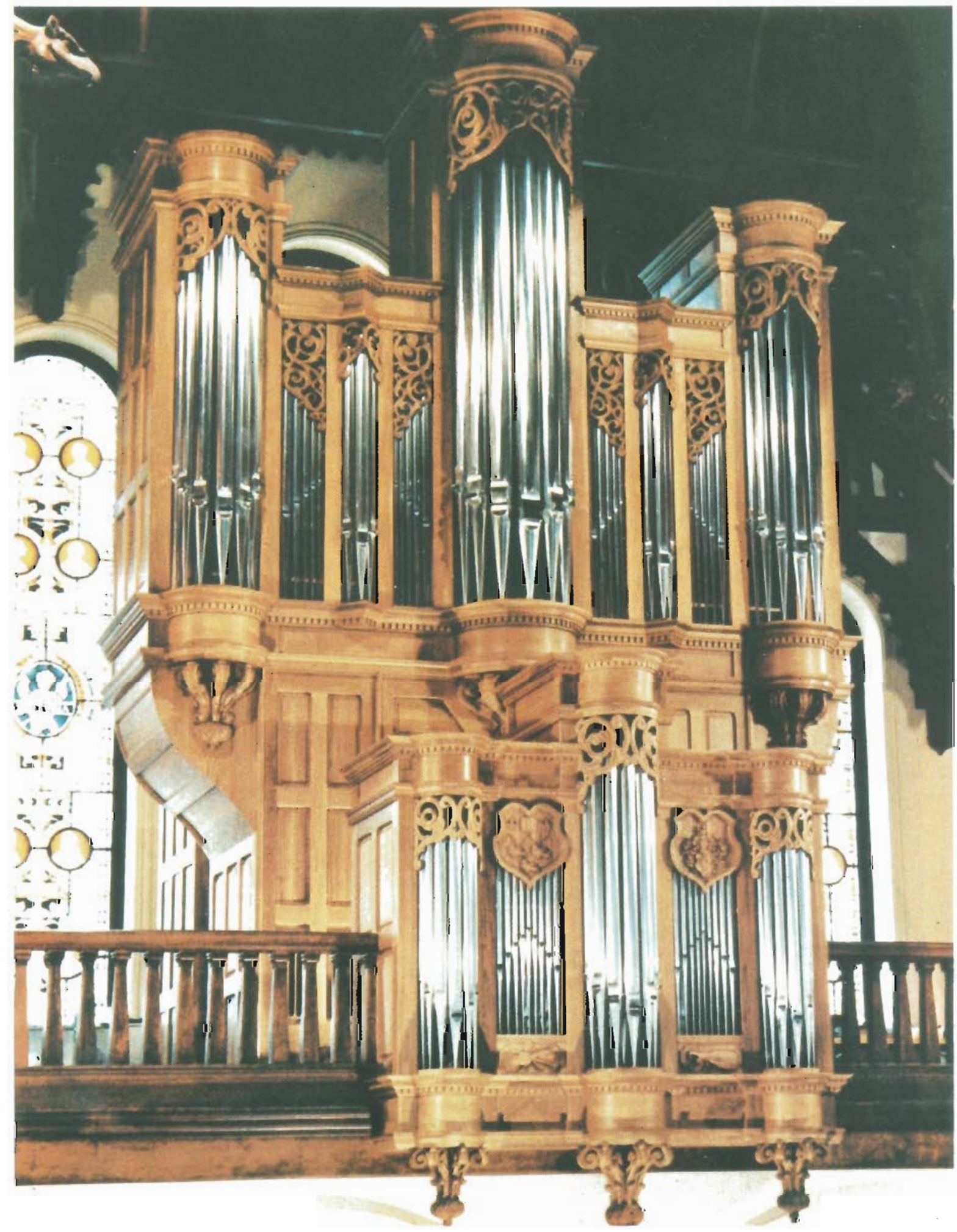

Organ, Redpath Ha!l, 1981. 
Celebrating Peter Redpath and His Library

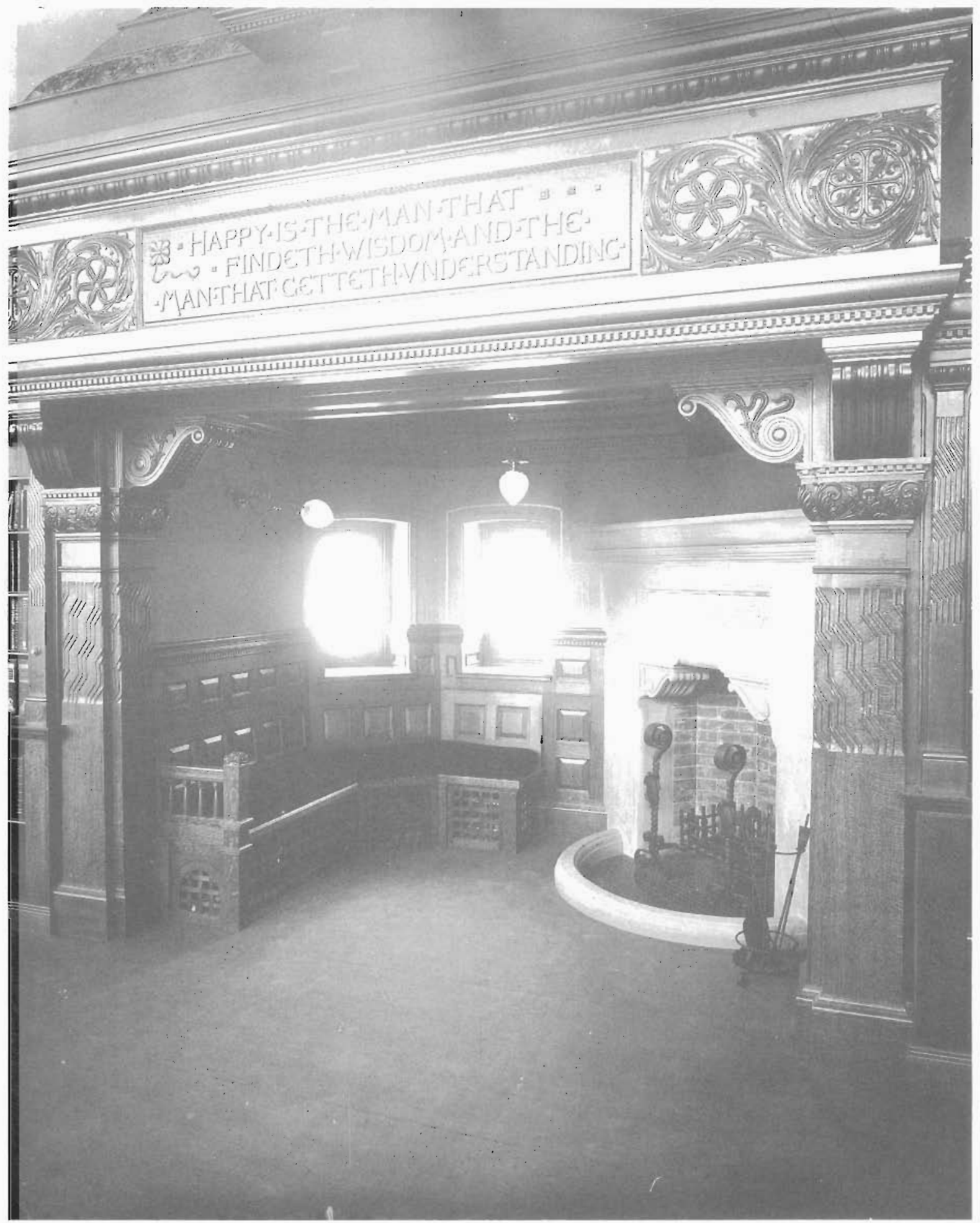

Fire-place and Mantel, Reading Room, Redpath Library, 1893. (Notman Photographic Archives, McCord Museum of Canadian History) 


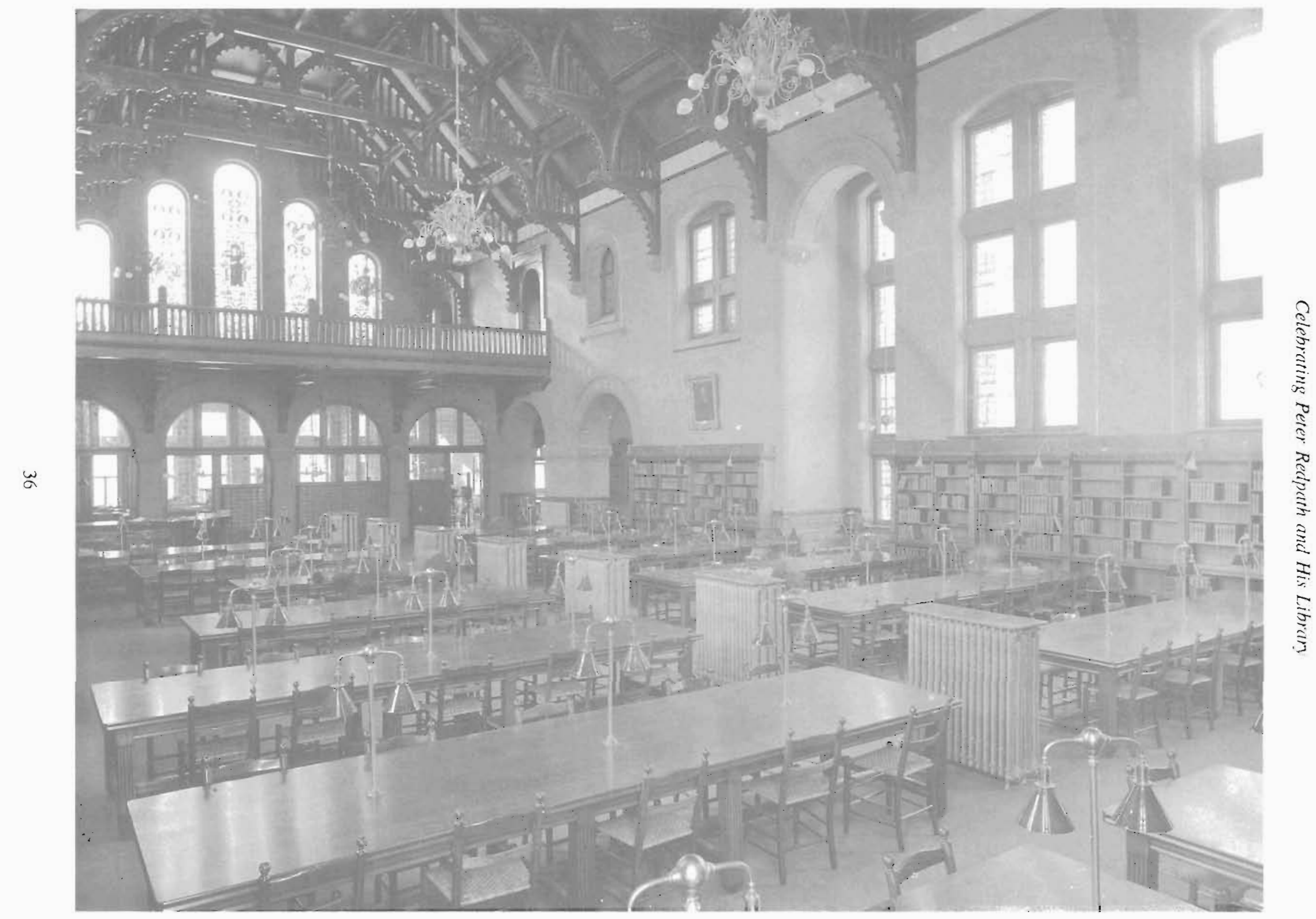

Reading Room, Redpath Library, 1893. (Notman Photographic Archives, McCord Museum of Canadian History) 


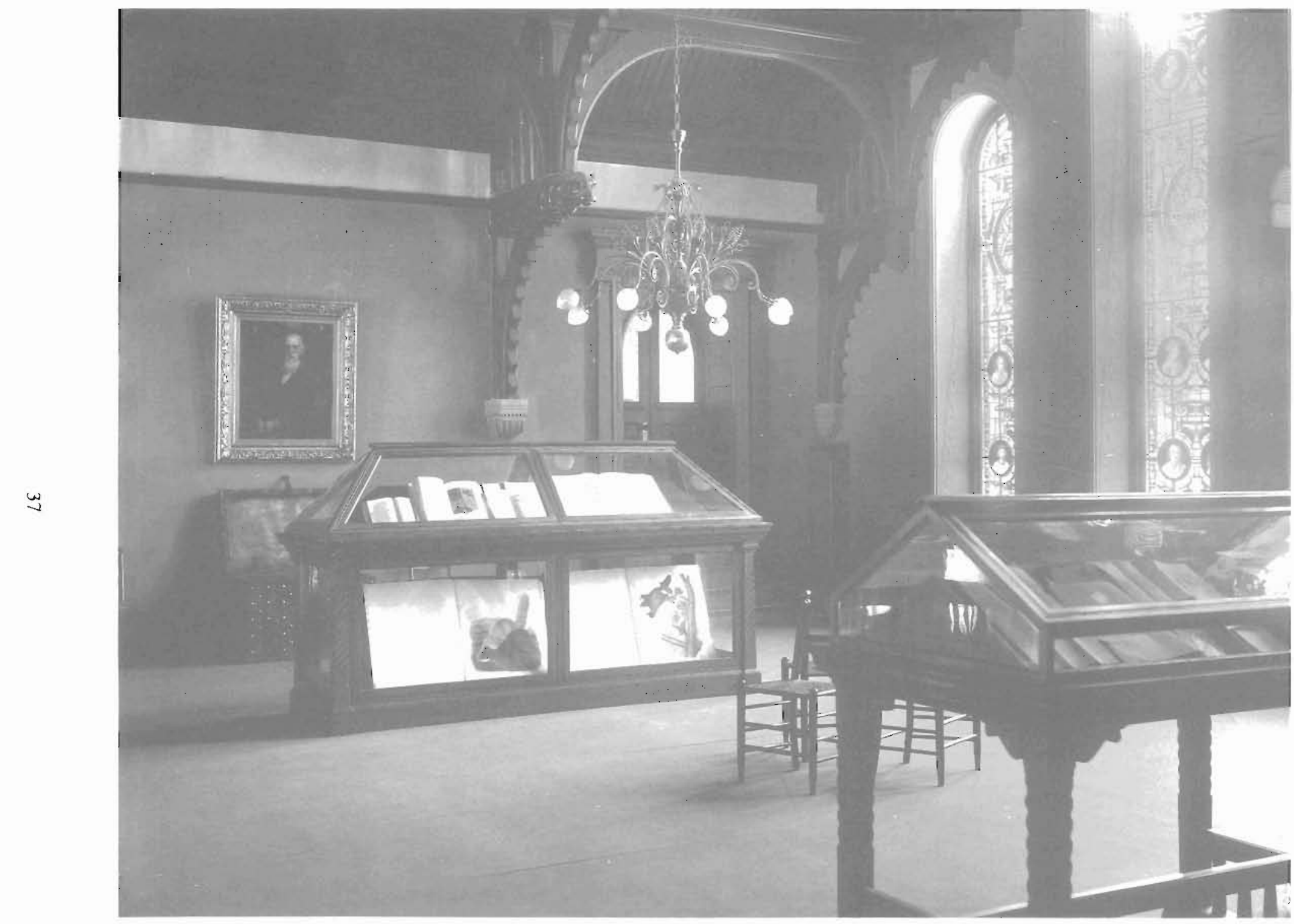

Exhibition Gallery. On display are two volumes of the J.J. Audubon double elephant folio Birds of America (1826-1838) - in the bottom of the case on the left - and a replica of the Domesday Book chest - on the left behind the Audubon. A facsimile of the Domesday Book and the chest were gifts of Peter Redpath in 1891. (Notman Photographic Archives, McCord Museum of Canadian History) 


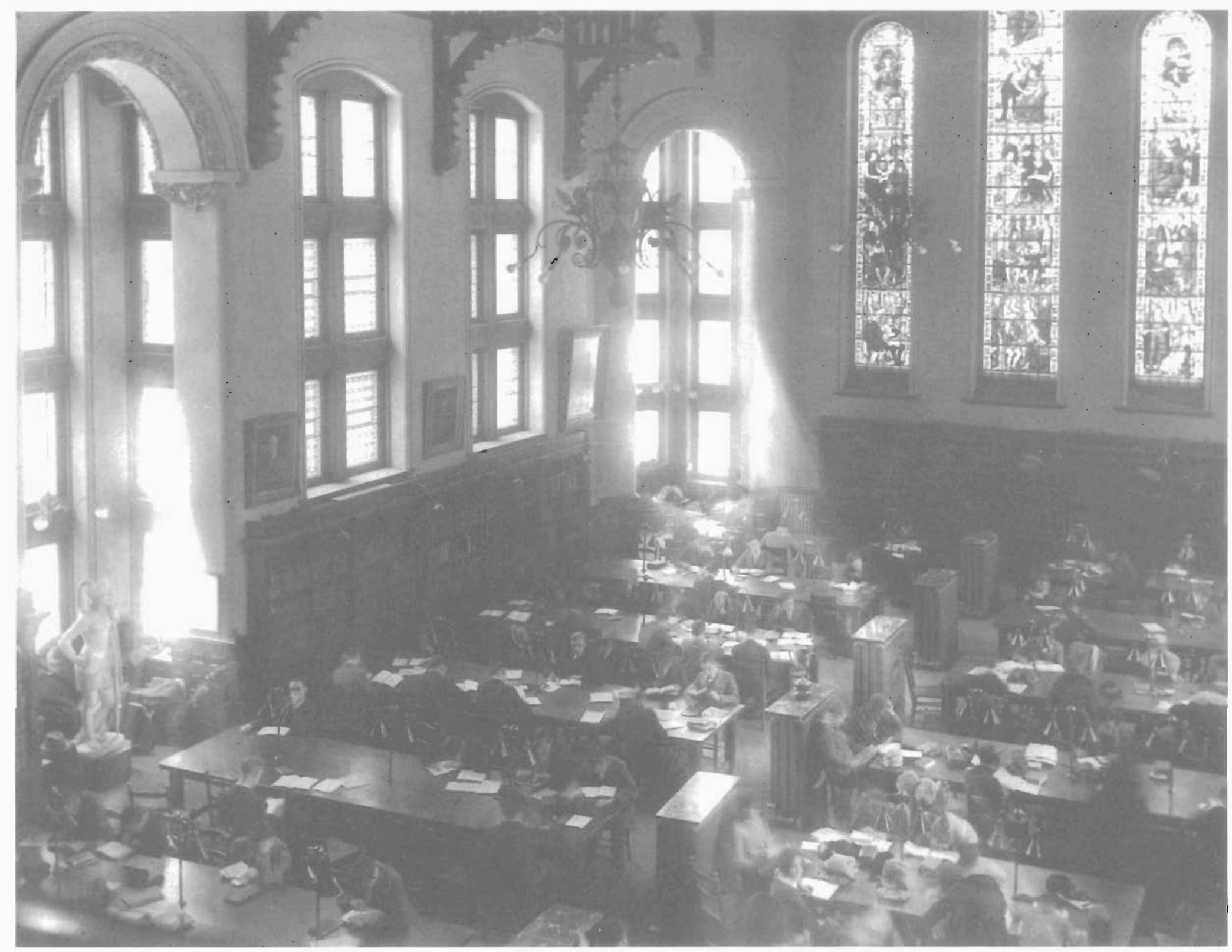

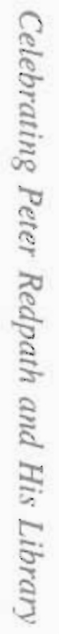




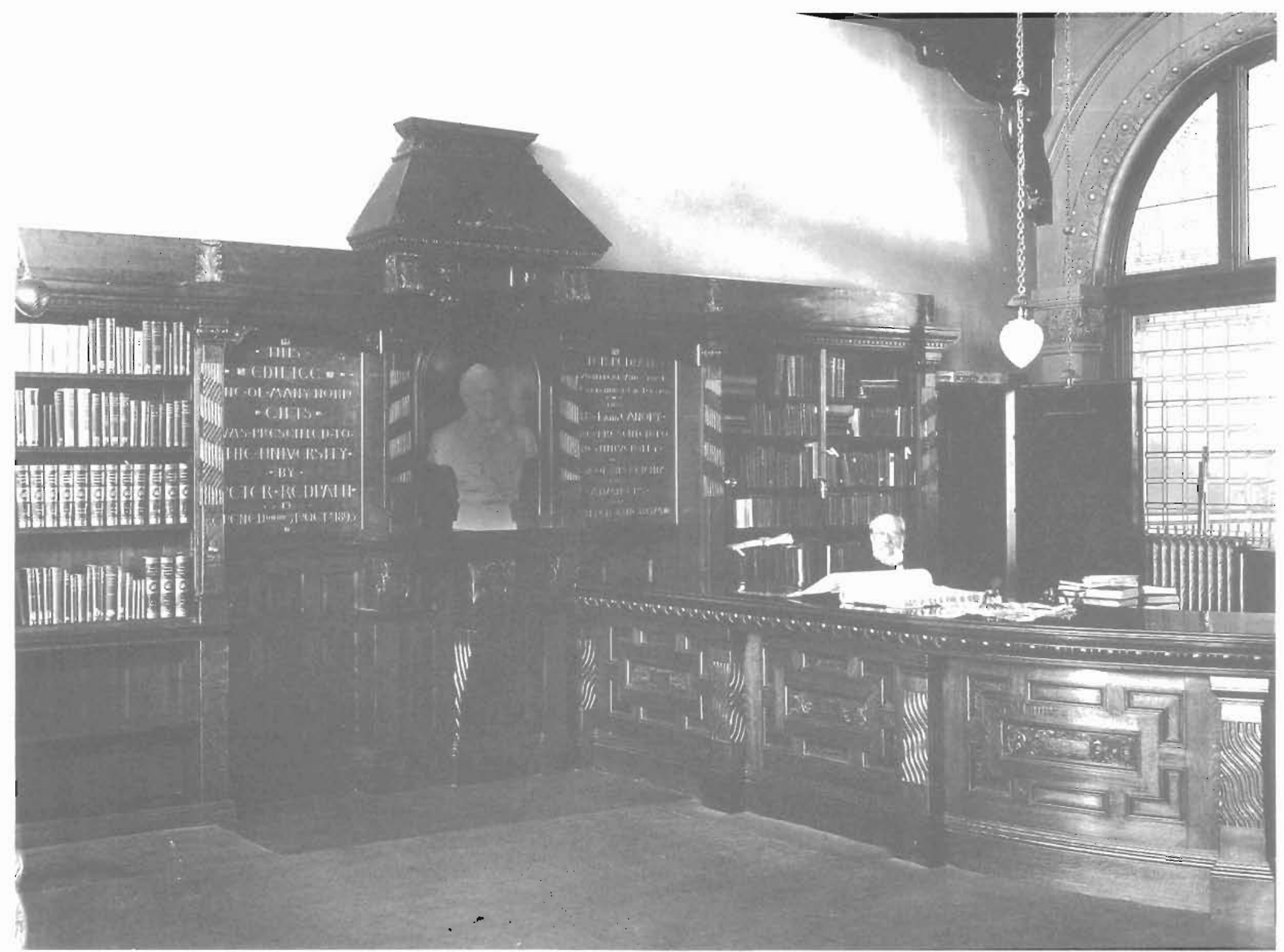

Circulation Desk, Redpath Library. The seated individual is probably Henry Mott, Assistant Librarian. (Notman Photographic Archives, McCord Museum of Canadian History) 


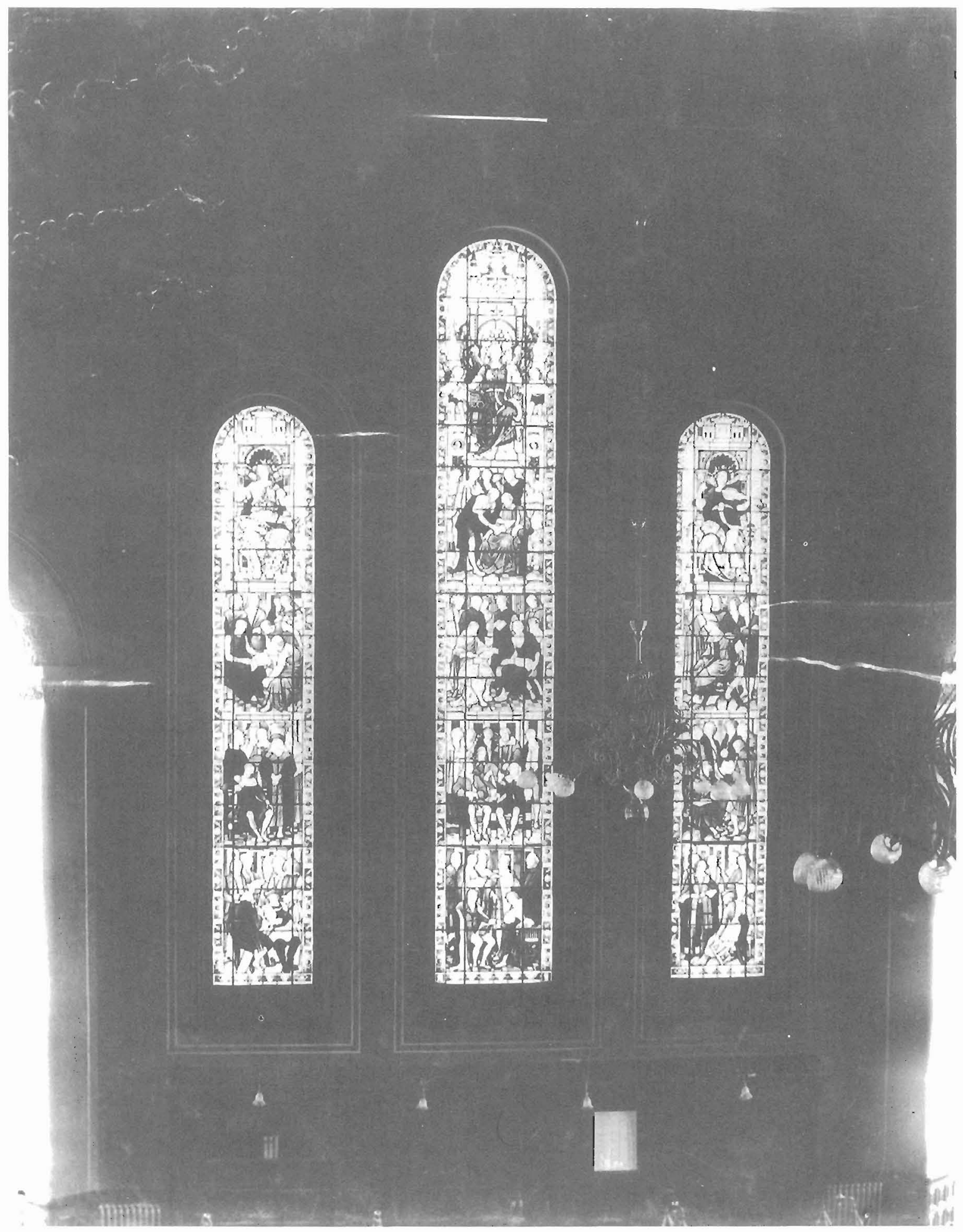

The three-light window, containing figures of great artists, poets and musicians, was the gift of Mrs. Peter Redpath, 1893. (Notman Photographic Archives, McCord Museum of Canadian History) 
Celebrating Peter Redpath and His Library

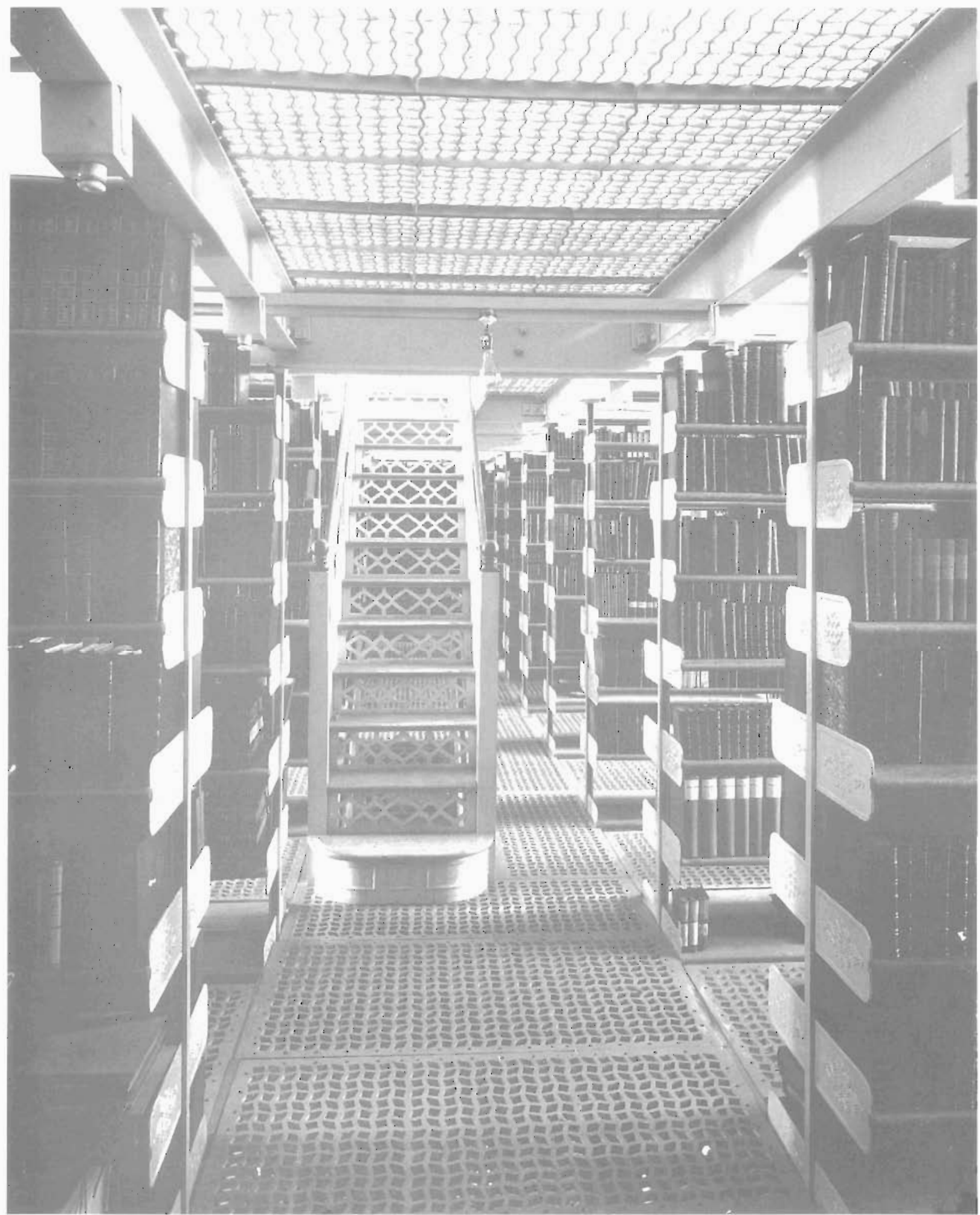

Stacks, Redpath Library, 1893. (Notman Photographic Archives, McCord Museum of Canadian History) 


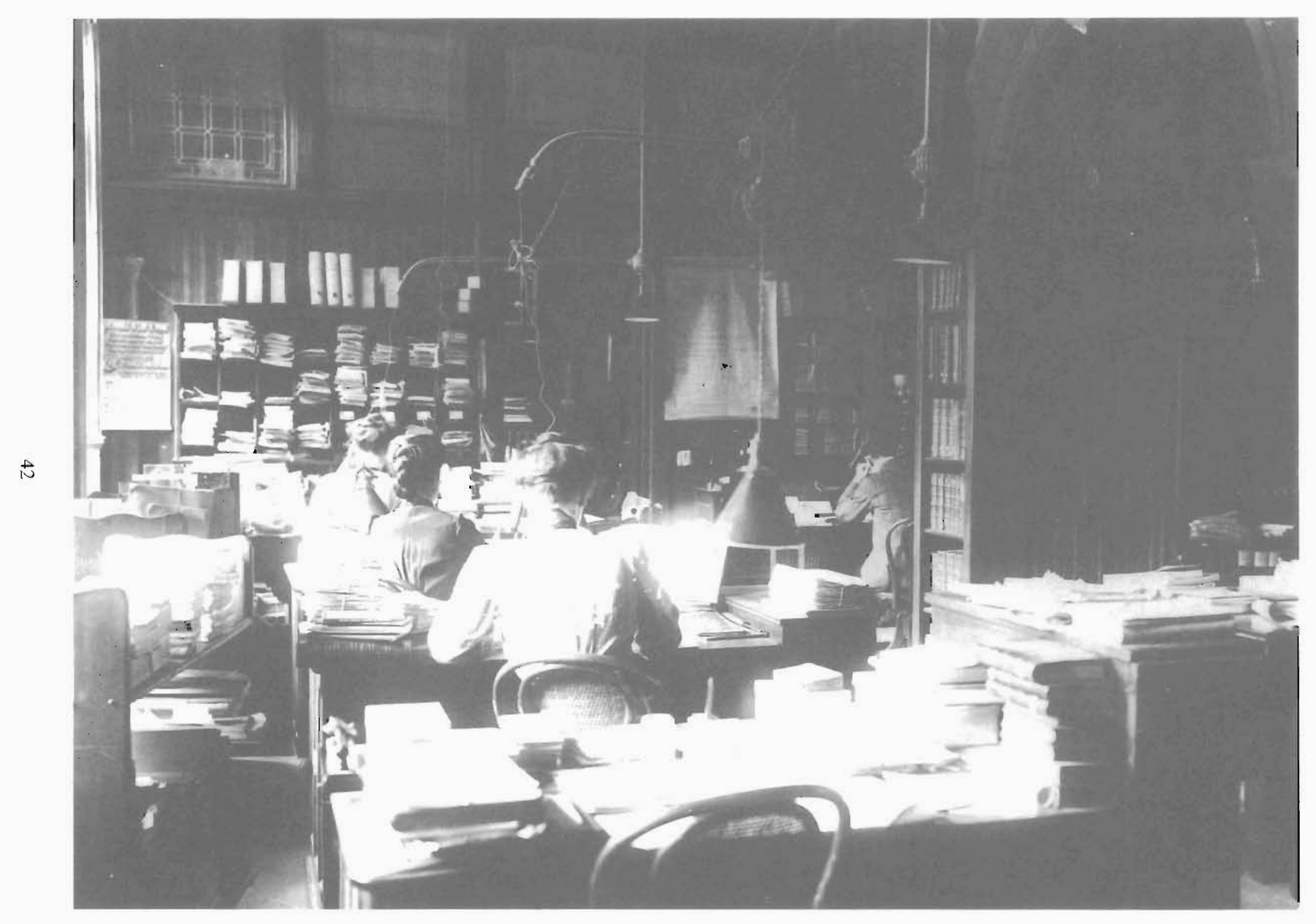

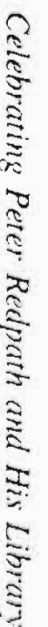

Cataloguers, Redpath Library ca. 1906. The seated male on the right is possibly Sydney Mitchell. (McGill University Archives) 


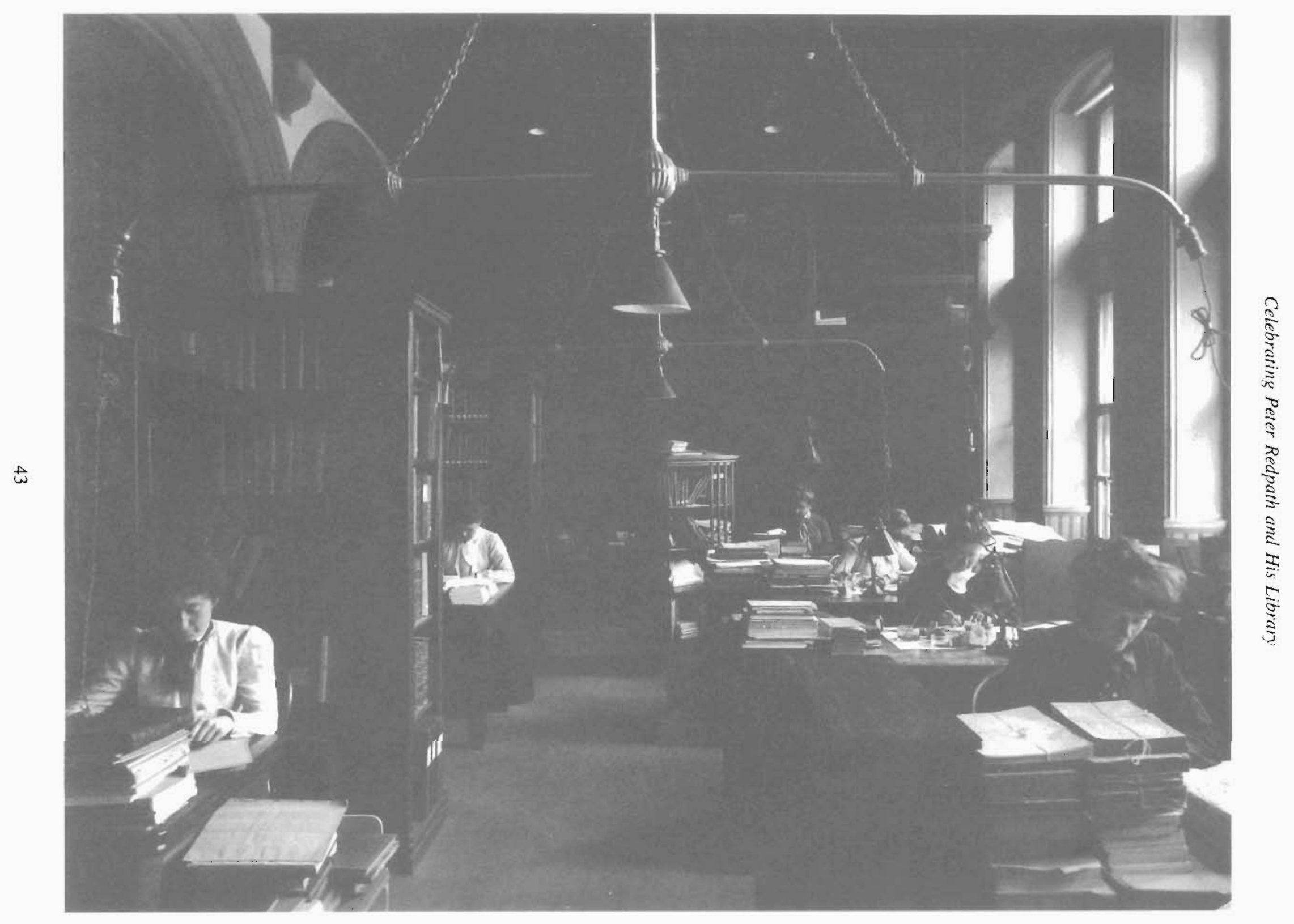

Cataloguers, Redpath Library ca. 1900. (McGill University Archives) 


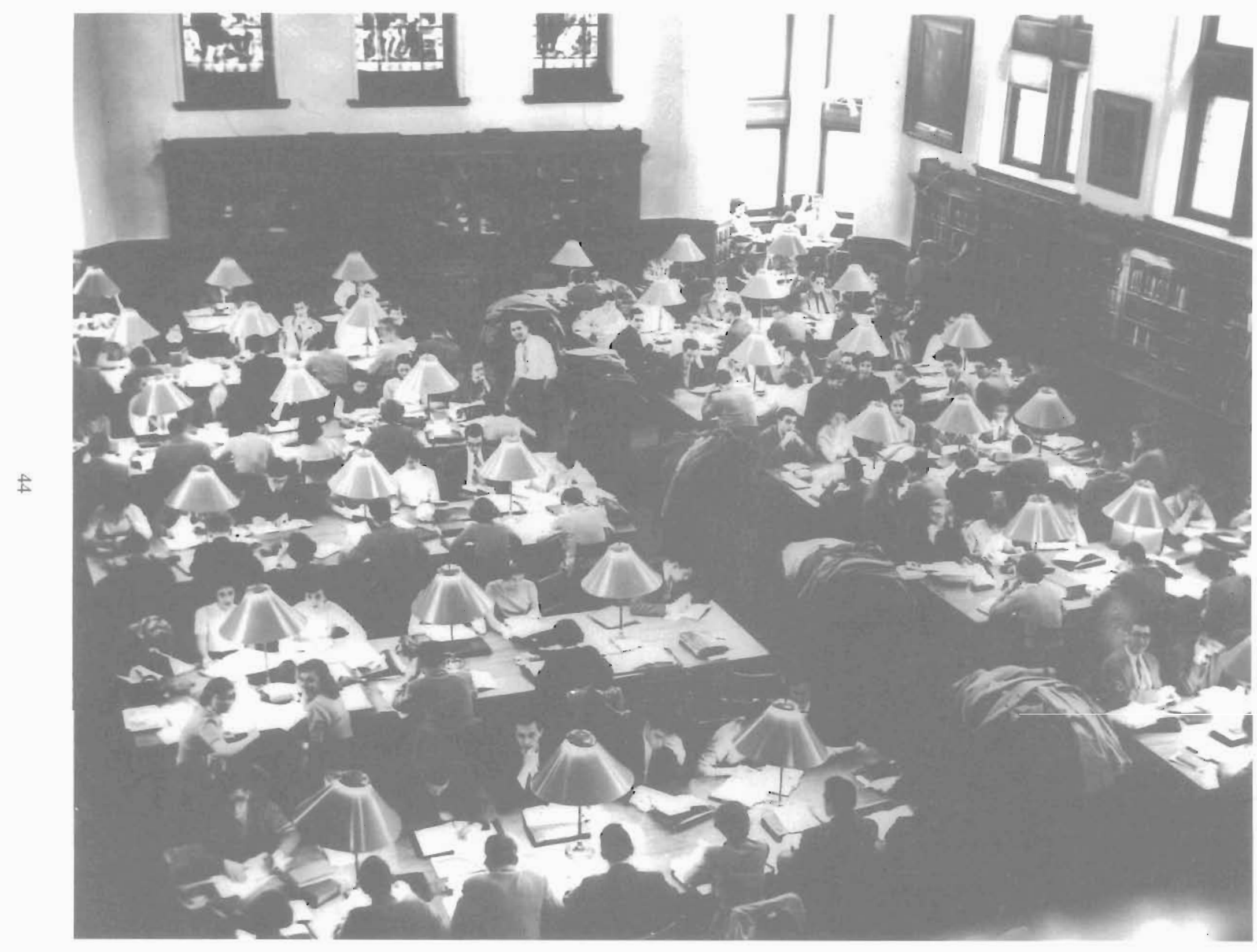

